University of South Florida

DIGITAL COMMONS

Digital Commons @ University of

@ UNIVERSITY OF SOUTH FLORIDA

South Florida

$12-18-2002$

\title{
Surface and Deep Ocean Circulation in the Subpolar North Atlantic During the Mid-Pleistocene Revolution
}

Amy K. Wright

University of South Florida

Benjamin P. Flower

University of South Florida, bflower@marine.usf.edu

Follow this and additional works at: https://digitalcommons.usf.edu/msc_facpub

Part of the Marine Biology Commons

\section{Scholar Commons Citation}

Wright, Amy K. and Flower, Benjamin P., "Surface and Deep Ocean Circulation in the Subpolar North Atlantic During the Mid-Pleistocene Revolution" (2002). Marine Science Faculty Publications. 23.

https://digitalcommons.usf.edu/msc_facpub/23

This Article is brought to you for free and open access by the College of Marine Science at Digital Commons @ University of South Florida. It has been accepted for inclusion in Marine Science Faculty Publications by an authorized administrator of Digital Commons @ University of South Florida. For more information, please contact digitalcommons@usf.edu. 


\title{
Surface and deep ocean circulation in the subpolar North Atlantic during the mid-Pleistocene revolution
}

\author{
Amy K. Wright and Benjamin P. Flower \\ College of Marine Science, University of South Florida, Florida, USA \\ Received 11 March 2002; revised 21 June 2002; accepted 30 July 2002; published 18 December 2002.
}

[1] We investigated surface and deep ocean variability in the subpolar North Atlantic from 1000 to 500 thousand years ago (ka) based on two Ocean Drilling Program (ODP) sites, Feni drift site $980\left(55^{\circ} 29^{\prime} \mathrm{N}\right.$, $\left.14^{\circ} 42^{\prime} \mathrm{W}\right)$ and Bjorn drift site $984\left(61^{\circ} 25^{\prime} \mathrm{N}, 24^{\circ} 04^{\prime} \mathrm{W}\right)$. Benthic foraminiferal stable isotope data, planktic foraminiferal faunas, ice-rafted debris data, and faunally based sea-surface temperature estimates help test the hypothesis that oceanographic changes in the North Atlantic region were associated with the onset of the 100kyr world during the mid-Pleistocene revolution. Based on percentage of Neogloboquadrina pachyderma (s) records from both sites, surface waters during interglacials and glacials were cooler in the mid-Pleistocene than during marine isotope stages (MIS) 5 and 6. In particular, interglaciations at Bjorn drift site 984 were significantly cooler. Faunal evidence suggests that the interglacial Arctic front shifted from a position between the two sites to a position northwest of Bjorn drift site 984 after ca. $610 \mathrm{ka}$. As during the late Pleistocene, we find faunal evidence for lagging surface warmth at most of the glacial initiations during the midPleistocene. Each initiation is associated with high benthic $\delta^{13} \mathrm{C}$ values that are maintained into the succeeding glaciation, which we term "lagging NADW production." These findings indicate that lagging warmth and lagging NADW production are robust features of the regional climate system that persist in the middle to late Pleistocene. INDEX TERMS: 4267 Oceanography: General: Paleoceanography; 3030 Marine Geology and Geophysics: Micropaleontology; 9325 Information Related to Geographic Region: Atlantic Ocean; 4870 Oceanography: Biological and Chemical: Stable isotopes; KEYWORDS: paleoceanography, foraminifera, stable isotopes, North Atlantic, mid-Pleistocene Ocean Drilling Program, leg 162

Citation: Wright, A. K., and B. P. Flower, Surface and deep ocean circulation in the subpolar North Atlantic during the midPleistocene revolution, Paleoceanography, 17(4), 1068, doi:10.1029/2002PA000782, 2002.

\section{Introduction}

\subsection{Mid-Pleistocene Revolution}

[2] The mid-Pleistocene revolution (MPR) is the name given to the period of time when the dominant periodicity of glacial-interglacial cycles changed from the 41-kyr obliquity signal to the 100-kyr eccentricity signal [Berger and Jansen, 1994]. The MPR occurred between about 1200 and $600 \mathrm{ka}$, although the exact timing is uncertain [e.g., Pisias and Moore, 1981; Prell, 1982; Ruddiman et al., 1989; Raymo et al., 1989; Berger et al., 1993; Berger and Jansen, 1994]. A large increase in Northern Hemisphere ice volume was followed by increased dominance of the 100-kyr period during the MPR (Figure 1). Benthic $\delta^{18} \mathrm{O}$ increased by about $0.29 \%$ at $\sim 920 \mathrm{ka}$ which corresponds to a sea level fall of about $30 \mathrm{~m}$ [e.g., Prell, 1982; Ruddiman et al., 1989; Mix et al., 1995]. This increase precedes the start of the dominance of the 100kyr period at about 650 ka [e.g., Mudelsee and Schulz, 1997; Maasch, 1988].

[3] The MPR is a major feature of the Pleistocene climate record that has yet to be adequately explained. In particular, it is not known why the $100-\mathrm{kyr}$ periodicity became

Copyright 2002 by the American Geophysical Union. 0883-8305/02/2002PA000782 dominant about $750-650$ ka while the $100-k y r$ eccentricity forcing declined. This "100-kyr problem" includes finding a mechanism that would amplify the climate system's response to relatively weak insolation forcing [Imbrie et al., 1993]. The lag between ice growth at $920 \mathrm{ka}$ and onset of the 100-kyr world at $\sim 750-650 \mathrm{ka}$ indicates decoupling between ice volume and the 100-kyr cycle [Mudelsee and Schultz, 1997].

[4] The MPR may have been associated with changes in deep ocean circulation. At mid-Atlantic Ridge site 607, which is an excellent monitor of North Atlantic Deep Water (NADW)/Southern Ocean Water (SOW) variability, Raymo et al. [1997] found greater suppression of NADW without any associated increase in the $\delta^{18} \mathrm{O}$ record from about 950 to $350 \mathrm{ka}$. This decoupling between ice volume and NADW variability may have been caused by greater sea-ice cover, which would cool the region and influence NADW production in the winter, but have little effect in the summer. Raymo [1997] attributed the MPR to the growth of larger Northern Hemisphere ice sheets after a long term, tectonically driven decrease in atmospheric $p \mathrm{CO}_{2}$, augmented by positive feedbacks in the climate system, including a decrease in NADW production.

[5] Venz et al. [1999] found percentage of ice-rafted debris (IRD) peaks at deglaciations throughout the MPR associated with $\delta^{13} \mathrm{C}$ minima at intermediate depth North 


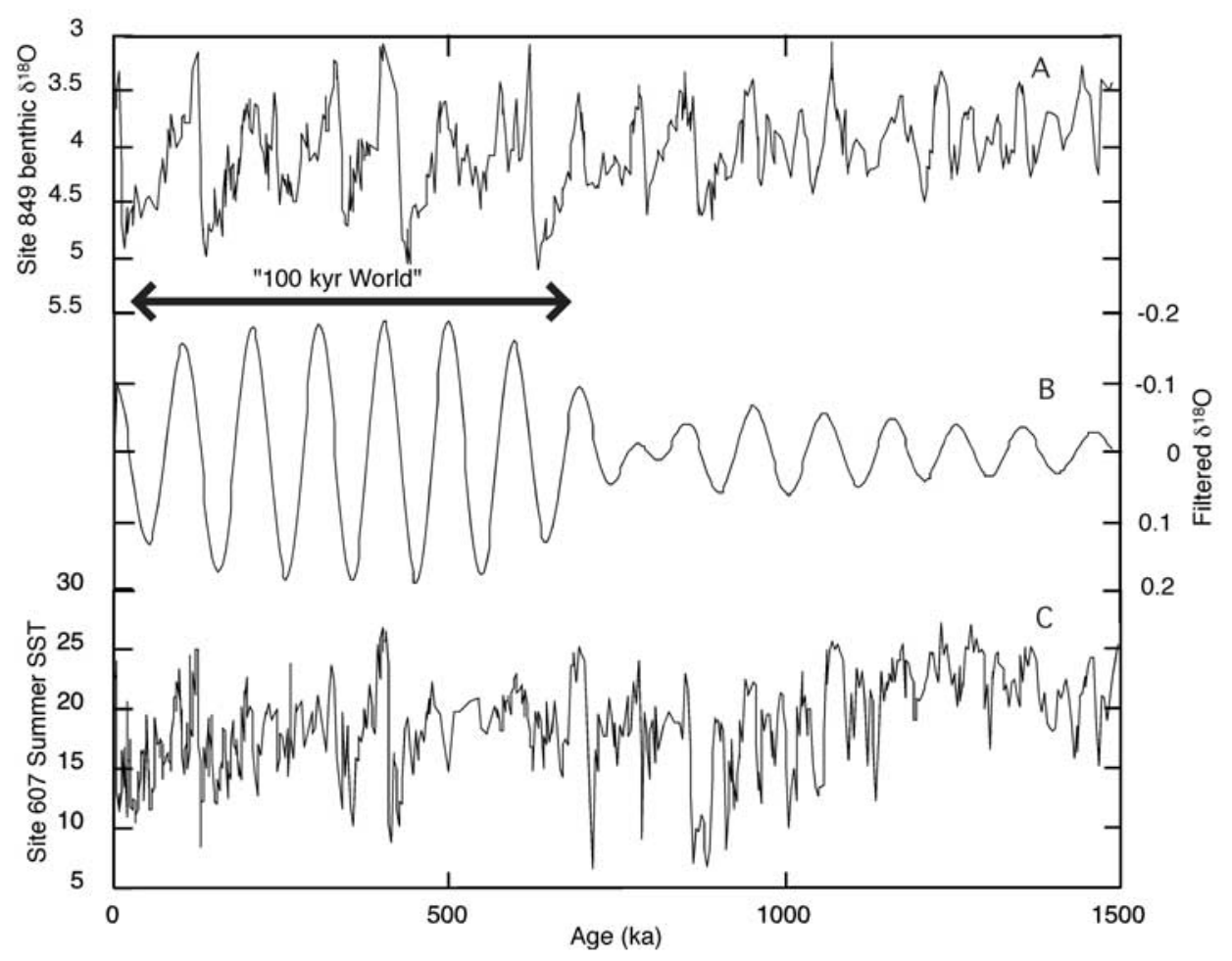

Figure 1. (a) Deep Pacific ODP site 849 benthic oxygen isotope record based on C. wuellerstorfi. (b) Same record filtered at $100 \mathrm{kyr}$ with a bandwidth of $0.0017 \mathrm{cycles} / \mathrm{kyr}$ [after Mix et al., 1995]. (c) North Atlantic site 607 SST record based on transfer function technique [Ruddiman et al., 1989]. Note the low SSTs during the mid-Pleistocene from $\sim 1000$ to $700 \mathrm{ka}$.

Atlantic site 982. The largest of these events, known as Terminal Ice Rafting Events (TIREs), occurred during MIS $24(\sim 920 \mathrm{ka})$ with a peak of over 90\% IRD that corresponds with a distinct minimum in $\delta^{13} \mathrm{C}$ at site 607 . This peak initiated a long-term trend of decreasing percentage of IRD peaks and lesser $\delta^{13} \mathrm{C}$ minima at glacial terminations beginning during MIS 24 ( 920 ka) and lasting until about 420 ka. This may be consistent with coeval trends in South Atlantic carbonate deposition [Schmieder et al., 2000] and NADW suppression [Raymo et al., 1997].

[6] During terminations of the last $1 \mathrm{Myr}$, Venz et al. [1999] suggested that production of Glacial North Atlantic Intermediate water decreased in part because of the melting of icebergs and low-salinity surface waters. This would have resulted in less ventilation of the mid-depth North Atlantic during terminations, sometimes lasting well into the interglacials before production of upper NADW resumed. Sea-ice cover may have reduced deep convection in the subpolar North Atlantic and led to NADW suppression. Sea-ice cover may also explain the decoupling found between global ice volume and deep water circulation because sea-ice coverage and marine ice shelves may have changed the location and impact of intermediate and deep water production, and may not have affected benthic $\delta^{18} \mathrm{O}$ values.

[7] Such changes in NADW formation may have been linked to changes in subpolar North Atlantic surface ocean- ography, because surface processes including advection of high-salinity Gulf Stream waters strongly influence deep convection in the Nordic Seas [Broecker, 1991]. In particular, a more southerly position of the Gulf Stream system and the Arctic front during glaciations would result in NADW formation in the subpolar North Atlantic as opposed to the Norwegian-Greenland Sea. Arctic front position and variability also affect poleward heat and moisture transport. Some evidence exists for cooler SSTs in the subpolar North Atlantic during the mid-Pleistocene, based on planktonic foraminifera faunal data from DSDP site 607 [Ruddiman et al., 1989]. A gradual increase in Transfer Function Technique (TFT) summer SSTs is seen from about 1000 to $700 \mathrm{ka}$, preceding the establishment of the 100-kyr world (Figure 1). Therefore changes in Arctic front variability from 1000 to 500 ka may have been associated with the initiation of the 100-kyr glaciations during the MPR.

\subsection{Glacial-Interglacial North Atlantic Arctic Front Swings}

[8] Surface ocean circulation is a major control of heat distribution throughout the North Atlantic [e.g., McCartney and Talley, 1984; Schmitz and McCartney, 1993]. The warm Gulf Stream in particular plays an important role in moving heat and moisture to the far north subpolar Atlantic during interglacials such as the present-day. The Arctic front is defined as the boundary between cold Arctic waters and 
warm Atlantic waters [e.g., Helland-Hansen and Nansen, 1909; Johannessen et al., 1994]. During the Holocene, the subpolar North Atlantic is characterized by a large east (warm) to west (cool) SST gradient; IRD deposition occurs only to the west of Iceland. This combination results in an Arctic front with a roughly southwest to northeast orientation, located west of Iceland. This pattern allows for a relatively large amount of heat and moisture transport toward the pole via the Gulf Stream system and associated NADW formation. Heat transport by the Gulf Stream system may help to keep the Fennoscandian region relatively warm today [e.g., Rahmstorf, 1994].

[9] During the LGM ( 20 ka), the warm Gulf Stream waters probably did not reach subpolar North Atlantic regions north of about $50^{\circ} \mathrm{N}$ [Climate, Long-Range Investigation and Mapping (CLIMAP), 1976; Ruddiman and McIntyre, 1981a; Hewitt et al., 2001]. The Arctic front was oriented roughly east-west, stretching from about Newfoundland to Portugal and IRD was deposited across the entire subpolar North Atlantic. This position resulted in low heat and moisture transport toward the pole. Deep convection occurring in the subpolar North Atlantic was associated with reduced poleward heat transport (the Boreal heat pump) compared to interglacial deep convection in the Nordic Seas (Nordic heat pump) [Lehman and Keigwin, 1992; Imbrie et al., 1992].

[10] In this paper, we use high-resolution isotopic, faunal, and percentage of IRD data to examine the detailed relationships among NADW formation, Arctic front variability, and the onset of the 100-kyr world. We find that changes in Arctic front variability are associated with the initiation of 100-kyr glaciations during the MPR, but that NADW exhibited variability similar to the late Pleistocene. We suggest that the mid-Pleistocene was associated with a more southerly interglacial Arctic front that shifted to the northwest during the late Pleistocene. Futhermore, glacial initiations were associated with lagging surface warmth and continued NADW production throughout the mid- to late Pleistocene.

\section{Study Area}

[11] The subpolar North Atlantic is a key area for the study of ocean circulation changes during the Pleistocene because of its proximity to and interactions with Northern Hemisphere ice sheets. Long cores of pelagic sediments with high-sedimentation rates, such as those recovered at several North Atlantic drift deposits by Ocean Drilling Program (ODP) Leg 162 are very useful for high-resolution studies [Jansen et al., 1996]. These high-sedimentation rate drift deposits are formed by deposition of fine-grained material by bottom currents; the interaction of currents with bathymetric features causes the fine-grained material to settle out, expanding the sediment sequences [McCave et al., 1995; Van Weering and Rijk, 1991].

[12] Site 984 is located on Bjorn drift, on the Reykjanes Ridge southwest of Iceland in about $1650 \mathrm{~m}$ water depth (Figure 2). It has high-sedimentation rates of about 5-12 $\mathrm{cm} / \mathrm{kyr}$ during the MPR [Shipboard Scientific Party, 1996]. The sediments are dominated by rapidly accumulating finegrained terrigenous particles and pelagic sediments. The dominant lithologies include silty clay, clay, clayey nannofossil mixed sediment, and clay with some nannofossils and silt. Ash layers are present through the upper sediment column and authigenic iron sulfides are common throughout. Nannofossil oozes with variable amounts of clay and sponge spicules also are present [Jansen et al., 1996]. Planktonic foraminifera are generally common and wellpreserved in the Pleistocene section [Flower, 1999].

[13] Site 980 is located on Feni drift, on the northwest flank of the Rockall Trough, west of Ireland in about 2100 $\mathrm{m}$ water depth (Figure 2). It also had a high-sedimentation rate of about $11.4 \mathrm{~cm} / \mathrm{kyr}$ during the MPR [Shipboard Scientific Party, 1996]. This area is influenced by geostrophic currents formed by Norwegian Sea overflow waters flowing across the Iceland-Scotland Ridge and by deeper, southern waters (including Antarctic Bottom Water). Sediments consist of rapidly accumulating nannofossil ooze with variable amounts of clays and clayey nannofossil sediments [Jansen et al., 1996]. Planktic foraminifera are abundant and well-preserved throughout the Pleistocene section [Flower, 1999]. Feni drift is located on the northern edge of the glacial North Atlantic IRD belt [Ruddiman, 1977; Ruddiman and McIntyre, 1981a, 1981b] and the Heinrich event zone [Heinrich, 1988] making it a good recorder of ice rafting derived from Hudson Bay, as well as Scandinavian and Greenland sources.

\section{Methods}

\subsection{Stable Isotopes}

[14] For site 980, oxygen and carbon isotope records were derived from the benthic foraminifer Cibicidoides wuellerstorfi. The bulk of this data was generated on a Micromass Precision Isotope Ratio Mass Spectrometer (PRISM) with a $90^{\circ} \mathrm{C}$ common acid bath in the Stable Isotope Laboratory, University of California, Santa Cruz. Analytical precision is better than $0.08 \%$ for $\delta^{18} \mathrm{O}$ and $0.05 \%$ for $\delta^{13} \mathrm{C}$. Specimens were sonicated in methanol to remove adhering fine particles and oven dried at $<50^{\circ} \mathrm{C}$. Data are reported relative to the Vienna Pee Dee Belemnite (VPDB) carbonate standard. Additional data were generated on a Finnigan DeltaPlus XL isotope ratio mass spectrometer equipped with a Kiel III automated carbonate preparation device at the University of South Florida. External precision based on over 400 NBS-19 standards run since July 2000 is better than $\pm 0.04 \%$ for $\delta^{13} \mathrm{C}$ and $\pm 0.08 \%$ for $\delta^{18} \mathrm{O}$. The site 980 benthic isotope record has an average temporal resolution of about 790 years (Figure 3). At site 984, oxygen isotope records, derived from the benthic foraminifer Cassidulina teretis have a resolution of about $2.5 \mathrm{kyr}$ (Figure 3).

\subsection{Foraminiferal Faunal Counts}

[15] Full planktic foraminiferal faunal counts were completed every $5 \mathrm{~cm}$ at site 980 and every $10 \mathrm{~cm}$ at site 984 . For each of these counts, the sample was split to about 500 grains, then species of planktonic foraminifera, benthic foraminifera, mineral grains, rock fragments, ash, radiolarians, sponge spicules, echinoid spines, ostracods, authigenic material, and planktic foraminifera fragments were counted. Average sample resolution was about 660 years at 


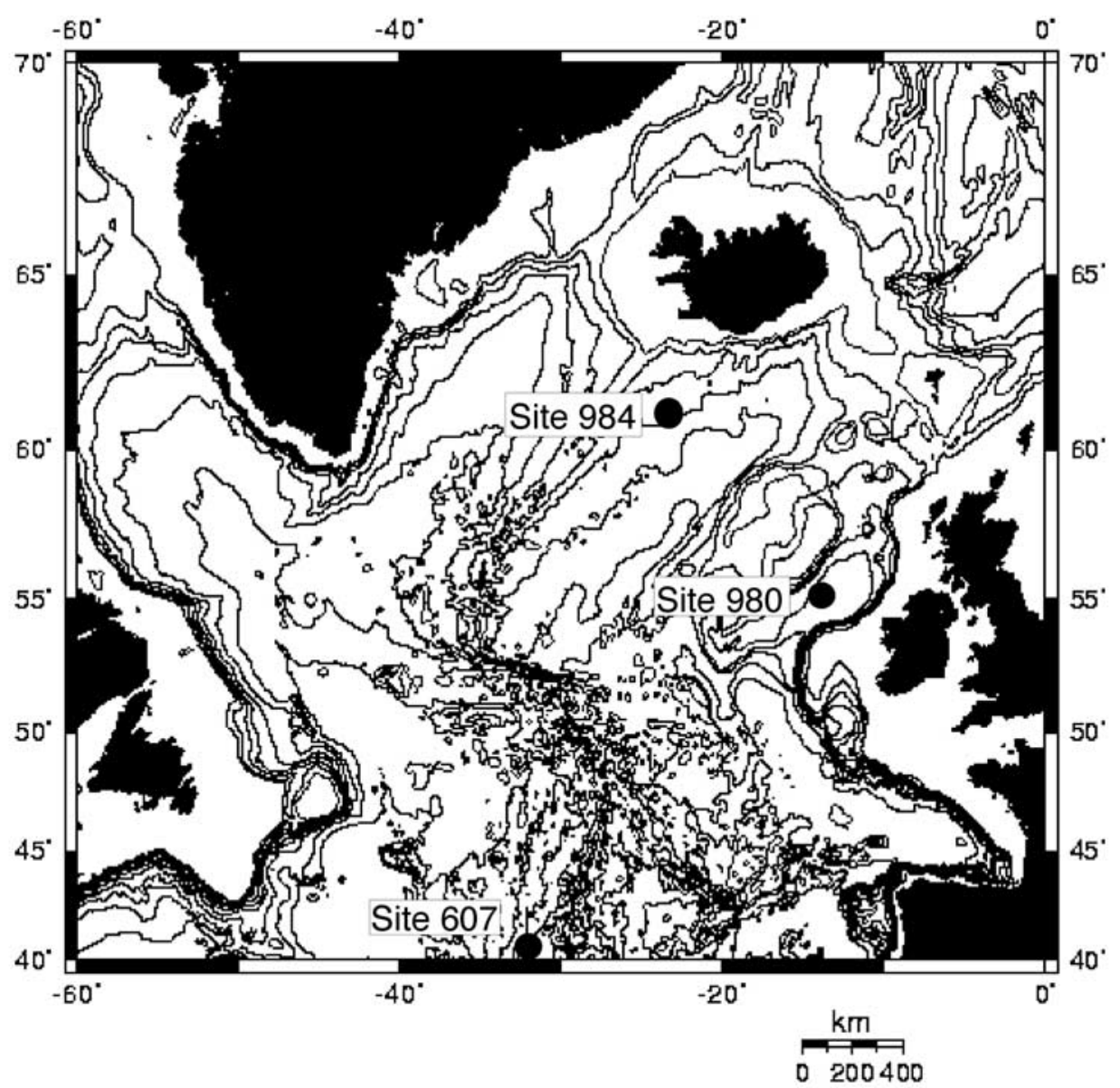

Figure 2. Subpolar North Atlantic Ocean Drilling Program sites 980 and 984 and Deep Sea Drilling Project site 607.

site 980 and 870 years at site 984 . IRD included mineral grains and rock fragments. ${ }^{1}$

\subsection{The Transfer Function Technique of SST Estimation}

[16] The Transfer Function Technique (TFT) of SST estimation uses factor analysis and multiple regression to transform faunal data into SST estimates [Imbrie and Kipp, 1971]. Down core faunal data are resolved into a number of factors that are related to modern SSTs by regression analysis. CLIMAP [1976] found that TFT is sensitive to the selection of the right number of factors and statistically relevant regression parameters, and that there was a problem with a restricted number of suitable modern analogs. The TFT uses an index called "communality" to estimate the quality of the SST estimate. Defined as the similarity between fossil and modern analogs, communality ranges from zero to one, with one being the best [e.g., Cline and Hays, 1976; Hutson and Prell, 1980; Prell, 1985; Guiot, 1991; Andersson, 1997].

${ }^{1}$ Supporting data will be available electronically at World Data CenterA for Paleoclimatology, NOAA/NGDC, 325 Broadway, Boulder, CO 80303, USA, or by phone at 303-457-6513, e-mail: paleo@mail.ngdc. noaa.gov; URL:http://www.ngdc.noaa.gov/paleo.
[17] At site 980, the mean communality throughout the interval $1000-500 \mathrm{ka}$ was 0.976 , with a summer glacial/ interglacial range of about $10^{\circ} \mathrm{C}$. At site 984 , the TFT SST estimates were suspect because of no-analog faunas.

\subsection{Modern Analog Technique Temperature Estimates}

[18] The Modern Analog Technique (MAT) of temperature estimation [Hutson, 1979; Prell, 1985] works by matching the faunal assemblages of down core samples with the assemblages seen in a worldwide modern core top environmental database. We used the core top faunal and SST data from 527 Atlantic cores in the Brown University core top database [Prell et al., 1999]. We used the program Analog [Prell, 1985] to compare our faunal assemblages at site 980 using the squared-chord dissimilarity measure. For each sample, the program selects the five modern-core top analogs closest to our data (defined as the lowest dissimilarity coefficients) and the summer and winter SSTs associated with these five analogs are averaged to get summer and winter SST estimates. The program derives a mean and a standard deviation of the dissimilarity coefficients and of the SST estimates for each of the five analogs.

[19] The MAT may offer several advantages over other faunal assemblage SST estimation programs. Prell [1985] 


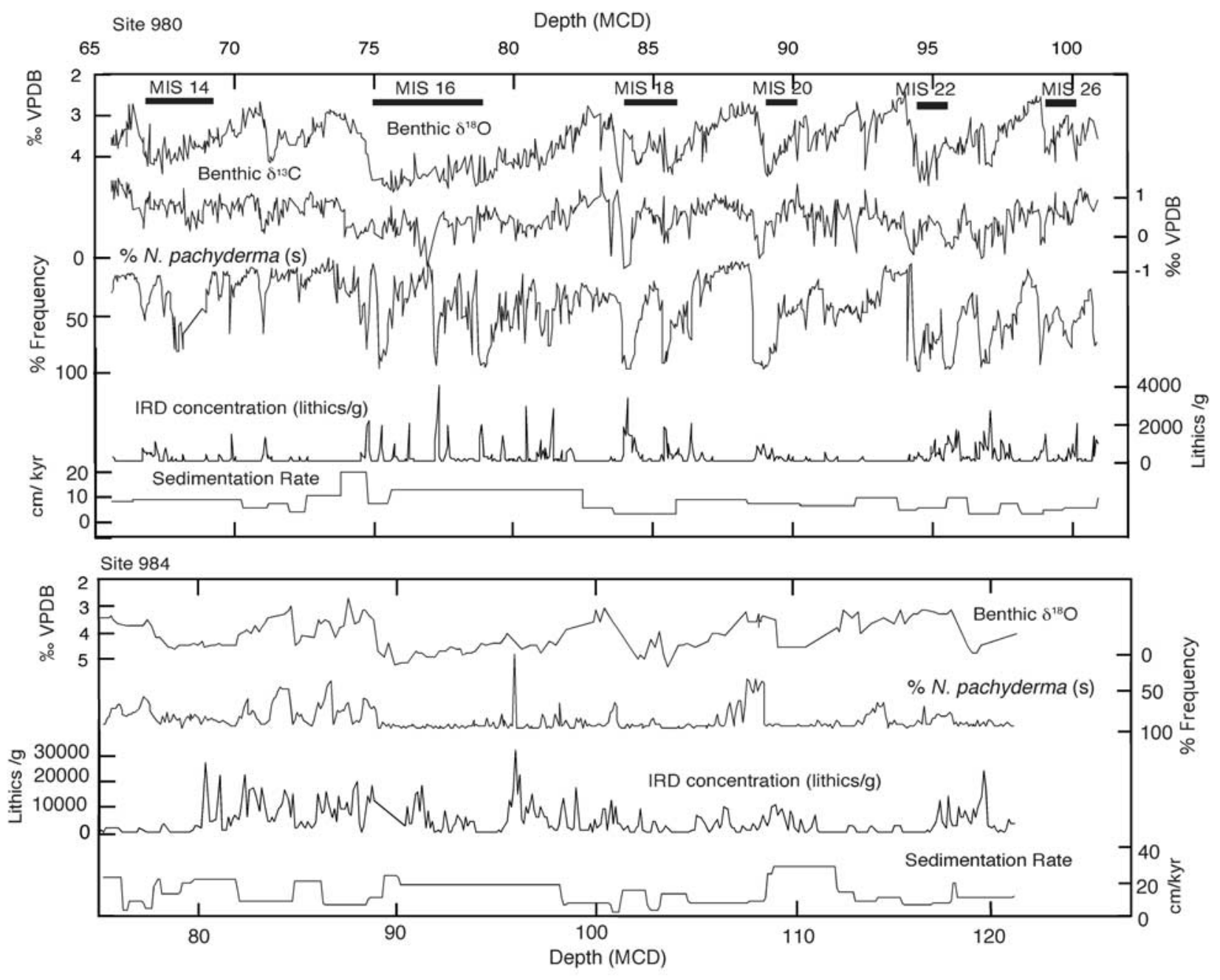

Figure 3. (top) Site 980 records versus depth in meters composite depth (mcd) with marine isotope stages marked. (bottom) Site 984 records versus depth (mcd). Benthic oxygen and carbon isotope records based on $C$. wuellerstorfi (site 980) and C. teretis (site 984; oxygen isotopes only).

found that the MAT estimated temperatures slightly more accurately than the CLIMAP [1981] equation did. MAT gives a measure of the success of temperature estimation of the samples against each of the top analogs individually, while the TFT precision is found more generally from the regression of all the samples. The standard deviation of the MAT temperature estimate is the range in temperature associated with that particular modern fauna. A high-dissimilarity coefficient indicates there is a no-analog condition, where no modern analogs exist in the core top database. At site 980, the mean-average dissimilarity coefficient through the interval 1000-500 ka was 0.09 with a standard deviation of 0.016 . These statistics are comparable to those considered acceptable for MAT applications by several earlier studies [e.g., Prell, 1985; Anderson et al., 1989; Oppo et al., 1997]. The average standard deviation of the SST estimates is $1.76^{\circ} \mathrm{C}$. Quality statistics associated with modern analog technique SST estimates at site 980 are as follows: dissimilarity, 0.0913; standard deviation, 0.0156; summer SST standard deviation, $1.82^{\circ} \mathrm{C}$; winter SST standard deviation, $1.70^{\circ} \mathrm{C}$.

[20] At northern site 984, the MAT SST estimates resulted in no-analog situations through most of our interval, which may indicate that site 984 was too cold to give reliable SST estimates with either the MAT or TFT techniques.

\subsection{Stratigraphy and Chronology}

[21] The timescale at site 980 was developed by correlating the benthic oxygen isotope record to the astronomically tuned benthic oxygen isotope record from deep Pacific site 849 [Mix et al., 1995]. The fit between these two curves is shown in Figure 4. Interpretation of the benthic isotope stratigraphy was aided by paleomagnetic stratigraphy. The Brunhes/Matuyama boundary (780 ka) [Shackleton et al., 1990] was located at 87.35 meters composite depth (mcd) and the Jaramillo chron (1050-990 ka) was located at 100.35-103.72 mcd. Our age model was then checked against the ice-volume model of Imbrie and Imbrie [1980], and minor corrections were made to improve the correla- 


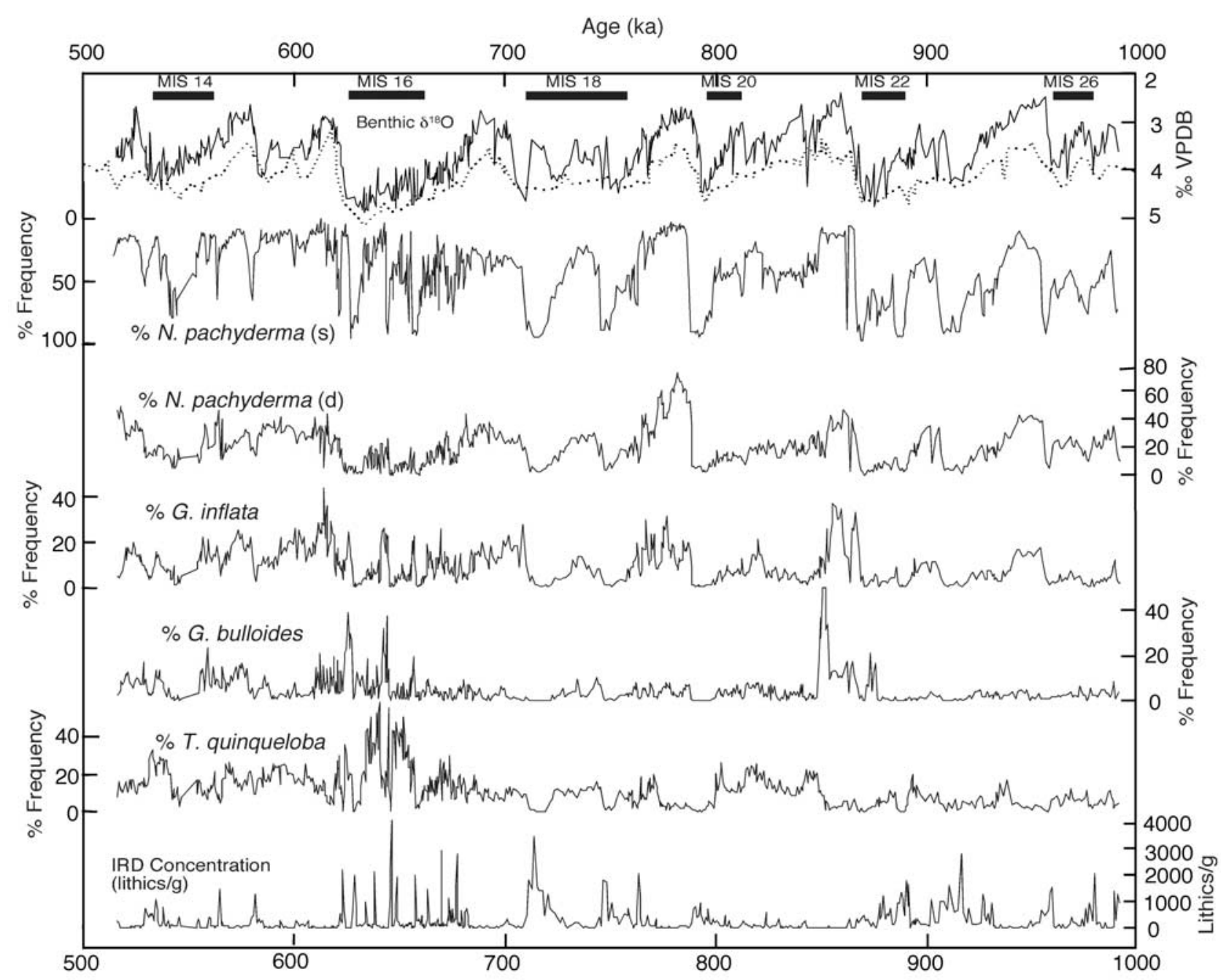

Figure 4. Site 980 faunal records versus age. Benthic oxygen isotope records based on C. wuellerstorfi from site 980 (solid line) and site 849 (dashed line) provided for reference, and MIS 14-26 marked.

tion, taking into account the possibility of subducted meltwater. Subducted meltwater is the idea that low $\delta^{18} \mathrm{O}$ values seen during deglacial times when IRD was still present were due to meltwater and that the interglacial did not start until the percentage of IRD was approximately zero [Lehman et al., 1993; Raymo et al., 1998; Oppo et al., 2001]. Raymo et al. [1998] found that at North Atlantic site 983 there was a link between deep water oxygen isotope events and IRD events in the surface waters that was not seen in the planktic oxygen isotope record. They argue that this was due to subduction of low-salinity meltwater in an area north of their site, affecting only the benthic isotope record. Oppo et al. [2001] refined their benthic oxygen isotope-based chronology for several cores in the subpolar North Atlantic using $\delta^{18} \mathrm{O}$ and percentage of IRD records such that the first low percentage of IRD $(\sim 6 \%)$ and low $\delta^{18} \mathrm{O}$ interval was assigned to be the beginning of the peak interglacial (Stage 5e).

[22] Because of the possibility of subducted meltwater influence during deglacial times, we allowed several of the decreases in the benthic $\delta^{18} \mathrm{O}$ records to be slightly older than the associated deglaciations in the ice-volume model [following Oppo et al., 2001]. This applied to benthic $\delta^{18} \mathrm{O}$ decreases just prior to MIS 14.0 (our age $=528 \mathrm{ka}$ ), 15.1 (579 ka), 16.0 (623 ka), 18.0 (712 ka), 20.0 (792 ka), and 22.0 (865 ka) [nomenclature from Prell et al., 1986], each of which is about $1-5 \mathrm{kyr}$ older than the associated icevolume decrease. Finally, we assumed that at site 980, the percentage of the polar foraminifer Neogloboquadrina pachyderma (sinistral or left coiling) could not exceed the percentages at the more northwest site 984 at any given time. This required minor modifications to the site 980 age model at MIS 18 (708 ka) and MIS 20.0 (789 ka). Our age model is an improvement on that found by Flower et al. [2000], which did not consider the possible effects of meltwater on the benthic oxygen isotope record.

[23] The age scale at site 984 was developed through magnetostratigraphy, with the Brunhes/Matuyama boundary at $107.84 \mathrm{mcd}$ and the top of the Jaramillo at $131.76 \mathrm{mcd}$, and correlation of the oxygen isotope record to the ice- 


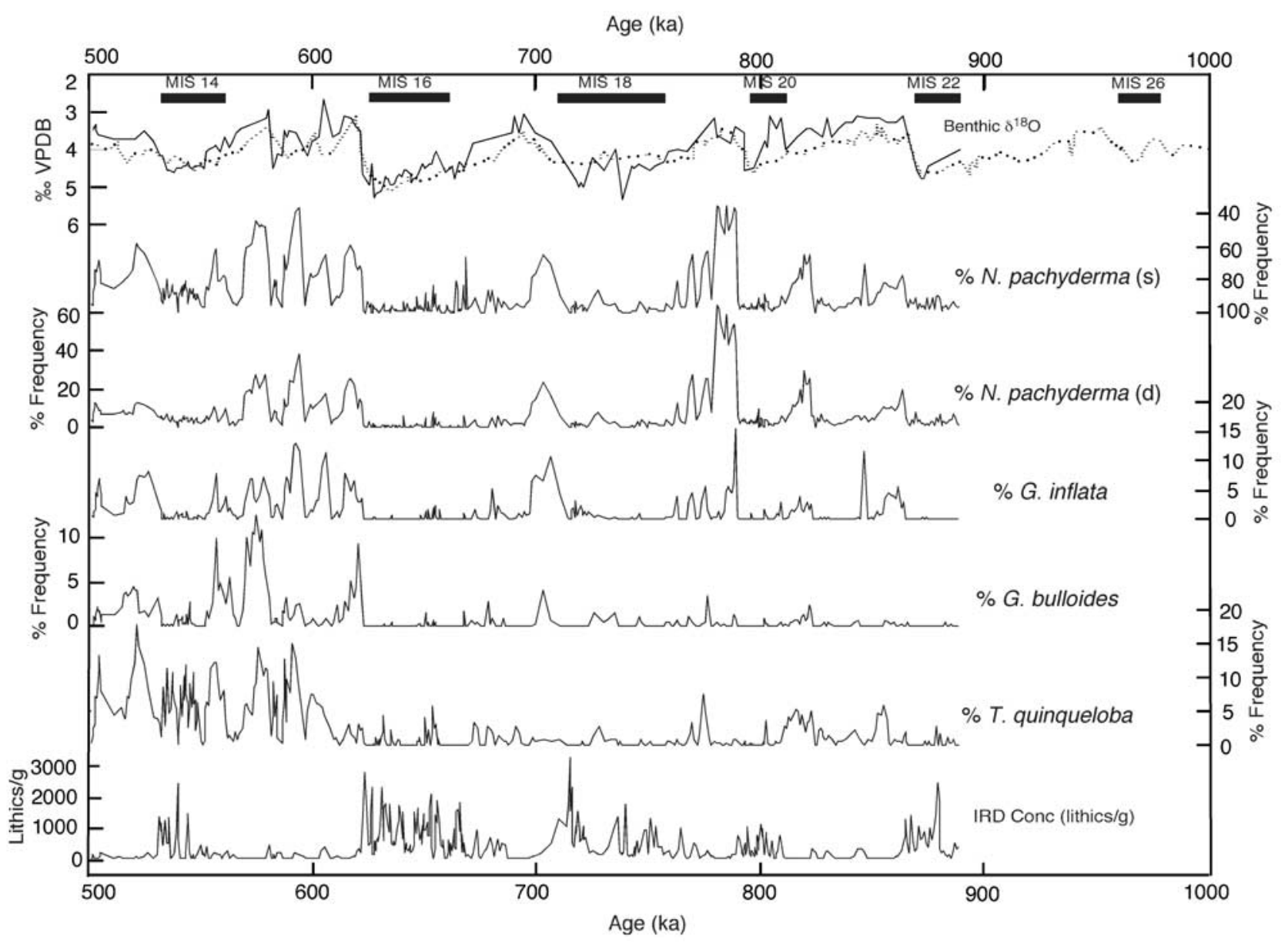

Figure 5. Site 984 faunal records versus age. Benthic oxygen isotope records based on C. teretis from site 984 (solid line) and on C. wuellerstorfi from site 849 (dashed line) provided for reference and MIS 14-26 marked.

volume model of Imbrie and Imbrie [1980]. Fit between the site 984 and site 849 oxygen isotope records is shown in Figure 5. We again considered the possibility of subducted meltwater signals in our record to allow decreases in the benthic $\delta^{18} \mathrm{O}$ records to be slightly older than the associated deglaciations in the ice-volume model.

\section{Results}

[24] The stable isotope records at site 980 span glacial/ interglacial cycles from MIS 14 to MIS 25, and from MIS 14 to 21 at 984 (Figure 3). Glacial/interglacial variations were also seen in the faunal data including the percentage of N. pachyderma (s) and percentage of IRD. At site 980, percentage of $N$. pachyderma (s) values range from about $\sim 3 \%$ in interglacials to about $\sim 98 \%$ during the glacials. More northern site 984 had higher values ranging from about 35 to $100 \%$. The percentage of $N$. pachyderma (dextral, or right-coiling) record showed glacial/interglacial patterns that were generally inverse of the $N$. pachyderma (s) record at both sites (Figures 4 and 5).

[25] There are 18 distinct cold peaks (values of greater than $75 \%$ ) in the percentage of $N$. pachyderma (s) record through the 1000-500 interval at site 980. During MIS 14, it exceeded $75 \%$ for 4 kyr. During MIS 16 there were five peaks above $75 \%$ of $1-5$ kyr duration. During MIS 18 there were peaks of 12 and $6 \mathrm{kyr}$ duration, one peak of $11 \mathrm{kyr}$ duration during MIS 20. There were five peaks during MIS 24-22 of 1-7 kyr duration. MIS 26 had three peaks of $1-3$ kyr duration (Figure 3).

[26] At site 984, the percentage of $N$. pachyderma (s) values were very high throughout the 1000-500 ka interval, only dropping below 75\% 13 times for about 1-12 kyr. During the peak interglacials of MIS 15 and 19 it reached its lowest values of about $35 \%$. The percentage of $N$. pachyderma (d) record only exceeded $25 \%$ six times in the $1000-$ $500 \mathrm{ka}$ interval, three times during MIS 16 for $1-3 \mathrm{kyr}$, twice during MIS 19 for $1-10 \mathrm{kyr}$ and once during MIS 21 for $1 \mathrm{kyr}$.

[27] The site 984 IRD number of lithics per gram dry weight sediment (lithics/g) record had generally higher values, at times an order of magnitude greater than at site 980. The concentration of IRD ranged from 0 lithics/g during interglacials to as high as 4144 lithics/g during glacials at site 980 and from 0 to 31,965 lithics/g at site 984 (Figures 4 and 5). While IRD concentrations at site 980 
during the 500-0 ka interval exceeded 1000 lithics/g 11 times [McManus et al., 1999], the 1000-500 ka interval exceeded 1000 lithics/g 23 times, with 10 of those peaks reaching greater than 2000 lithics/g. Throughout the 1000 $0 \mathrm{ka}$ interval, IRD peaks at glacial terminations were often associated with negative excursions in the benthic $\delta^{13} \mathrm{C}$ record [McManus et al., 1999; this paper, Figure 4].

\section{Discussion}

\subsection{Sea-Surface Temperature History}

[28] For the 1000-500 ka interval at Feni drift site 980, our TFT-derived SST estimates compare well with earlier faunally derived SST estimates from the last few glacial/ interglacial cycles (Figure 6). Glacial/interglacial summer temperature ranges of about $8^{\circ}-10^{\circ} \mathrm{C}$ are consistent with findings on late Pleistocene SST in this region [e.g., CLIMAP, 1976; Ruddiman and McIntyre, 1979, 1981a, 1984; Ruddiman and Esmay, 1987]. Our MAT SST data from site 980 (Figure 6) differed from these late Pleistocene SST estimates. Glacial/interglacial temperatures exhibited a range of about $8^{\circ}-10^{\circ} \mathrm{C}$ after $700 \mathrm{ka}$ and $10^{\circ}-14^{\circ} \mathrm{C}$ before $700 \mathrm{ka}$. Throughout the $1000-500 \mathrm{ka}$ MAT SST record, glaciations were about $1^{\circ}-2^{\circ} \mathrm{C}$ cooler and interglaciations were warmer by about $1^{\circ}-5^{\circ} \mathrm{C}$ than the late Pleistocene.

[29] The larger range of MAT SST before about $710 \mathrm{ka}$ is highlighted by the $20^{\circ} \mathrm{C}$ summer temperatures during interglacials MIS 19 and 21, which is not seen in our TFT record. The squared-chord dissimilarity measure that we used in our MAT SST estimates is usually the most reliable equation for running the MAT [e.g., Prell, 1985]. Experiments with MAT equations other than the squaredchord dissimilarity from 1000 to $500 \mathrm{ka}$ at site 980 also gave these unusually warm temperatures, so they are not an artifact of the equation used. The use of five analogs, rather than 10 produced an insignificant decrease in temperatures at MIS 19 and 21. During the unusually warm times, analogs from the South Atlantic, particularly off the coast of Northwest Africa and near the center of the South Atlantic gyre occurred more frequently than any other time.

[30] The TFT record at site 980 did not show the extreme summer interglacial warming during MIS 19 and 21 seen in the MAT SST estimate (Figure 6). Ruddiman et al. [1987] found very low temperatures in their TFT SST estimates from temperate North Atlantic site 607 at glacial MIS 22 and 18. They found a tendency for these events to be immediately followed by relatively high-SST estimates in the succeeding interglacials MIS 21 and 17. While our record did not show the extreme cold at MIS 22 and 18 noted by Ruddiman et al. [1987], it does show extreme warmth during one of the following interglacials (MIS 21).

[31] Ruddiman et al. [1987] believed that these SST events in their record were real and not artifacts of the SST-estimation process because their faunal counts supported these extremes in temperature. Likewise, in our site 980 records, both warm events at MIS 19 and 21 had percentage of $N$. pachyderma (s) values near zero for the longest interval $(<10 \%$ for $11 \mathrm{kyr}$ at MIS 19 and $6 \mathrm{kyr}$ at
MIS 21) in our entire record. The percentage of $N$. pachyderma (d) had its highest values in our record at these two warm times of $>40 \%$ for $11 \mathrm{kyr}$ at MIS 19 and $5 \mathrm{kyr}$ at MIS 21. The Globoconella inflata record indicated warmth at both MIS $19(\sim 30 \%)$ and MIS $21(\sim 35 \%)$. The Globigerina bulloides record had its largest peak of $\sim 55 \%$ at MIS 21 . Significantly, site 984 showed a major warming event at MIS 19, although the MIS 21 warming was much smaller (Figure 6). Although their magnitudes may be uncertain, it is clear that MIS 19 and 21 were distinctly warm intervals in the northeastern subpolar North Atlantic.

[32] The percentage of $N$. pachyderma (s) values at site 980 during MIS $5(0 \%$ N. pachyderma (s)) and MIS $6(90 \%$ $N$. pachyderma (s)) [Oppo et al., 2001] were generally lower than the 1000-500 ka interval at site 980. From 1000 to $500 \mathrm{ka}$ interglacial values were consistently $3-5 \%$ which showed that SSTs might have been cooler than during the $500-0$ ka interval. $N$. pachyderma (s) values from 1000 to $500 \mathrm{ka}$ were about $5 \%$ higher than those from MIS 6 at almost all the glacials. This indicates that it may have been generally cooler in the Feni drift region during both glaciations and interglaciations during the $1000-500 \mathrm{ka}$ interval than during the late Pleistocene. This is consistent with the TFT SST results. We did not find that sea-surface conditions were especially cool during MIS 18, 22, and 24 as found during other glaciations in the North Atlantic [Ruddiman et al., 1987] (Figure 6).

[33] At site 984, percentage of $N$. pachyderma (s) values from 1000 to 500 ka were significantly higher than those of nearby core EW9302-8JPC from MIS $6(\sim 90 \%)$ and 5 ( $\sim 0 \%)$ [Oppo et al., 2001]. During the 1000-500 ka interval at site 980 , glaciations had almost $100 \% N$. pachyderma (s), resulting in a difference of about $10 \%$. However, during interglaciations, the percentage of $N$. pachyderma (s) only dropped as low as $\sim 25-50 \%$ resulting in a large difference of $\sim 50-75 \%$ during interglacials between MIS 5 and interglacials from 1000 to $500 \mathrm{ka}$ in the Bjorn drift (Figure 6). This implied that interglacials from 1000 to $500 \mathrm{ka}$ were significantly cooler than MIS 5 on Bjorn drift.

\subsection{Arctic Front Variability}

[34] To investigate the variability of the position of the Arctic front we compared percentage of $N$. pachyderma (s) and percentage of Turborotalia quinqueloba records through the 1000-500 ka interval. Johannessen et al. [1994] found that the Arctic front is characterized by a switch between dominance of $N$. pachyderma (s) in arctic water, to increased $T$. quinqueloba near the sea-ice edge in North Atlantic water. We use this switch in relative abundance of these two taxa to track the position of the Arctic front (Figure 7).

[35] At site 980 from 1000 to 700 ka during glacials, the percentage of $N$. pachyderma (s) values were generally high $(>80 \%)$, and the percentage of T. quinqueloba values were low $(>10 \%)$, indicating that the Arctic front was probably to the south of the Feni drift area. During interglacials, the percentage of $N$. pachyderma (s) values were significantly lower and the percentage of $T$. quinqueloba values remained low. This may indicate that the Arctic front swung north of the Feni drift area during interglacials. Just after the peak 


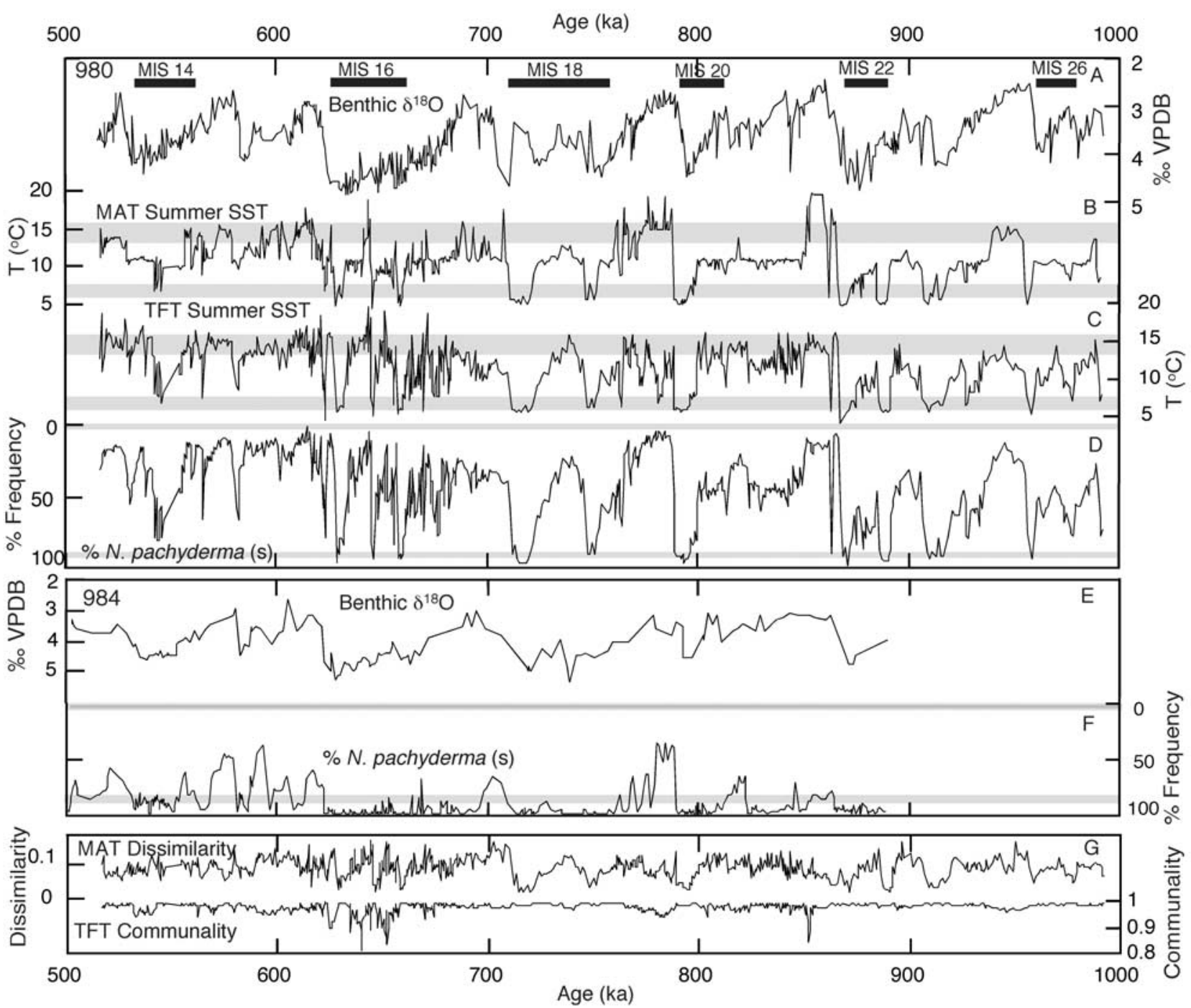

Figure 6. At site 980 (a) benthic oxygen isotope curve, (b) summer MAT SST, and (c) summer TFT SST records compared to summer SST estimates for the late Pleistocene (gray bars) for this area. Upper gray bar is $12^{\circ}-16^{\circ} \mathrm{C}$ average interglacial and lower bar is $6^{\circ}-8^{\circ} \mathrm{C}$ average glacial SST estimates from cores near site 980 (RC9-225, CH73128, K708-1, K708-7, V23-82) [Ruddiman and McIntyre, 1979, 1981a]. Note that the TFT SST range throughout the record at site 980 is similar to the late Pleistocene estimates. At site 980, (d) percentage of $N$. pachyderma (s) compared to levels from MIS 5 and 6 [Oppo et al., 2001]. Note similar percentage of $N$. pachyderma (s) range compared to the late Pleistocene values. At site 984 (e) benthic oxygen isotope record and (f) percentage of $N$. pachyderma (s) compared to values for MIS 5 and 6 from nearby core EW9302-8JPC [Oppo et al., 2001]. Note higher percentage of $N$. pachyderma (s) during glaciations and especially during interglaciations at site 984 throughout the 1000-500 ka interval, compared to the late Pleistocene. (g) Measures of the success of the SST estimations from site 980 .

interglacials, as the percentage of N. pachyderma (s) record began to increase indicating that the area was cooling, there was often an increase from $\sim 10$ to $20 \%$ in percentage of $T$. quinqueloba of $\sim 3-7 \mathrm{kyr}$ duration, which is consistent with the Arctic front passing southward over Feni drift during glacial initiations. This was seen at MIS 25/24, 23/22, 21/ 20, and 19/18 (Figure 7). Beginning at MIS 16 at about 660 $\mathrm{ka}$, percentage of $T$. quinqueloba values became higher overall. The only times that percentage of T. quinqueloba returned to very low values is during the extremely cold glacial pulses in the percentage of $N$. pachyderma (s) record (Figure 7). This may mean that the Arctic front was located near the Feni drift area throughout much of this interval, resulting in high percentage of T. quinqueloba values, and occasionally moved south of Feni drift during glaciations.

[36] Data from northern site 984 confirm this pattern. The percentage of $N$. pachyderma (s) values were very high 


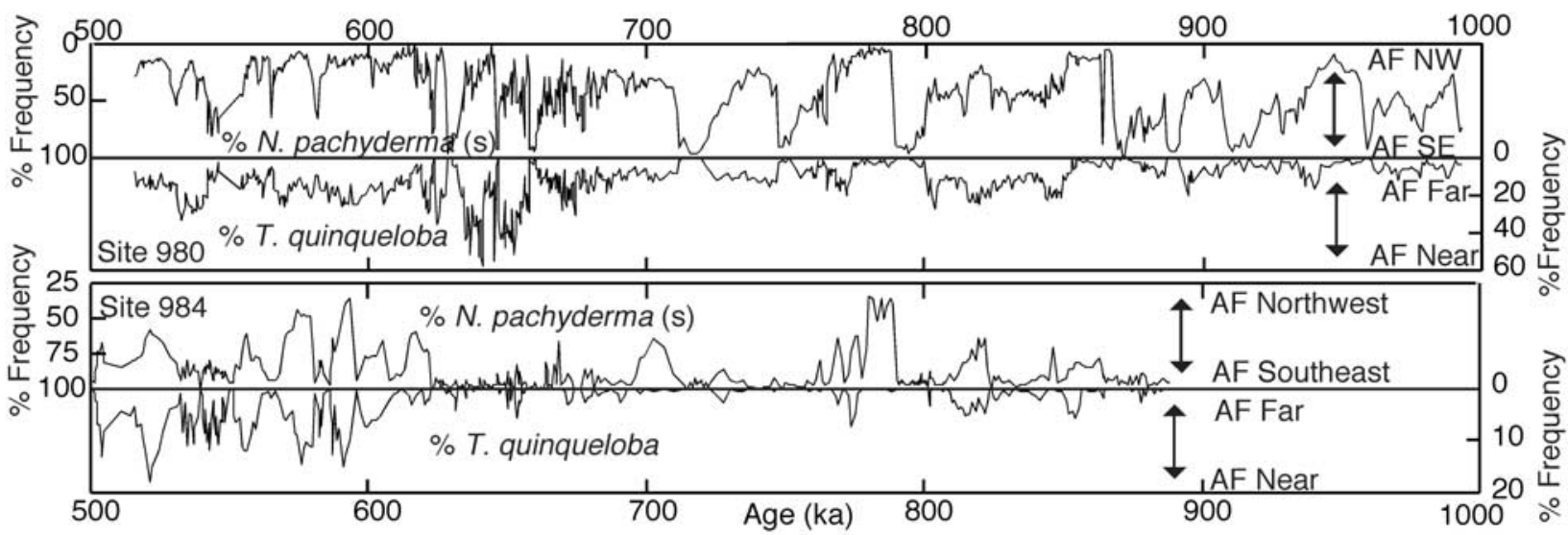

Figure 7. Arctic-front (AF) indicator percentage of $N$. pachyderma (s) and sea-ice edge indicator percentage of T. quinqueloba at sites 980 and 984 from 1000 to $500 \mathrm{ka}$. Arrows on percentage of $N$. pachyderma (s) records indicate that when percentages are high, the Arctic front is southeast (SE) of a given site, and when low is northwest $(\mathrm{NW})$ of the site. Arrows on percentage of T. quinqueloba records show that high percentages indicate the Arctic front was near the site, and low percentages mean the Arctic front was far from the site. Together, the records suggest a northwest shift of the Arctic front over site 980 during MIS 16 at $~ 660 \mathrm{ka}$, and a further northwest shift over site 984 during MIS 15 at $\sim 610 \mathrm{ka}$.

$(>80 \%)$ and the percentage of $T$. quinqueloba values were very low $(<5 \%)$ through most of the record from $1000 \mathrm{ka}$ to about $610 \mathrm{ka}$ (Figure 7). This is consistent with our suggestion that the Arctic front was generally to the south of the area for much of this time. There are small excursions of the percentage of $T$. quinqueloba record as seen at site 980 just after the warm interglacial percentage of $N$. pachyderma (s) values at MIS 21/20 and 19/18, indicating that the Arctic front may have moved over the area at these times. After MIS 16, beginning at about 610 ka percentage of $T$. quinqueloba values were generally higher, reaching $15 \%$ especially during times with lower percentage of $N$. pachyderma (s) (>60\%), which may indicate that the Arctic front moved closer to the Bjorn drift and moved across the area several times after about $610 \mathrm{ka}$ (Figure 7). Together, the sites 984 and 980 data suggest that before $\sim 660 \mathrm{ka}$ the glacial Arctic front was most often south of Feni drift and moved northward after $\sim 660 \mathrm{ka}$. Similarly, the interglacial Arctic front shifted northward over Bjorn drift after $\sim 610$ ka (Figure 8).

[37] Overall, the faunal data from sites 980 and 984 indicate that there may have been a significant change in surface water conditions in the subpolar North Atlantic from about 660 to $610 \mathrm{ka}$. There does not seem to be a corresponding change in deep circulation, as discussed in a later section.

\subsection{Bond Cycles During MIS 3-2 Versus MIS 16}

[38] During MIS 3-2, there were six major ice-rafting events called Heinrich Events 1-6 [e.g., Heinrich, 1988; Broecker et al., 1990]. They occurred about 7-10 kyr apart, with the final event coinciding with the Younger Dryas event [e.g., Bond et al., 1992]. Most events were accompanied by low-foraminifera concentrations dominated by $N$. pachyderma (s), indicating extreme cold. Superimposed on this variability was a series of high-frequency SST variations, termed "Bond cycles" [e.g., Broecker et al., 1990]. Five of the six Heinrich events were found to occur at the end of the cool phase of a Bond cycle and were followed by warming to almost interglacial temperatures [Bond et al., 1992].

[39] In our records of MIS 16 at southern site 980, we found five events with percentage of IRD greater than $70 \%$, each of which was accompanied by high $(>70 \%) \mathrm{N}$. pachyderma (s) (Figure 9). There were five other significant events of $30-40 \%$ IRD, all of which correspond to high percentage of $N$. pachyderma (s) ( $\sim 55-90 \%)$. Of the total of ten events, seven of them followed the pattern of gradual cooling culminating in a Heinrich-like event, followed by rapid warming.

[40] This evidence implies that Bond cycles and Heinrichlike events occurred during the mid-Pleistocene, at least during MIS 16 in the northeast Atlantic. At northern site 984, where the IRD is derived primarily from nearby Iceland, with possible contributions from East Greenland, Svalbard, around the Arctic Ocean and western Europe, there were many more high percentage of IRD events, and the percentage of $N$. pachyderma (s) values were high throughout, but only one or two IRD events coincide in time to the Heinrich-like events at site 980. This may indicate that site 984 was outside the belt of Heinrich-like events during the mid-Pleistocene, as during the late Pleistocene. SST variations and IRD peaks exhibit a similar timing and geographic pattern during MIS 16 and MIS 3-2 in the subpolar North Atlantic, suggesting a similar variability in surface conditions.

\subsection{Glacial Terminations}

[41] The question of whether subpolar North Atlantic surface waters lead or lag global ice-volume change has 
(A) Before MIS 16

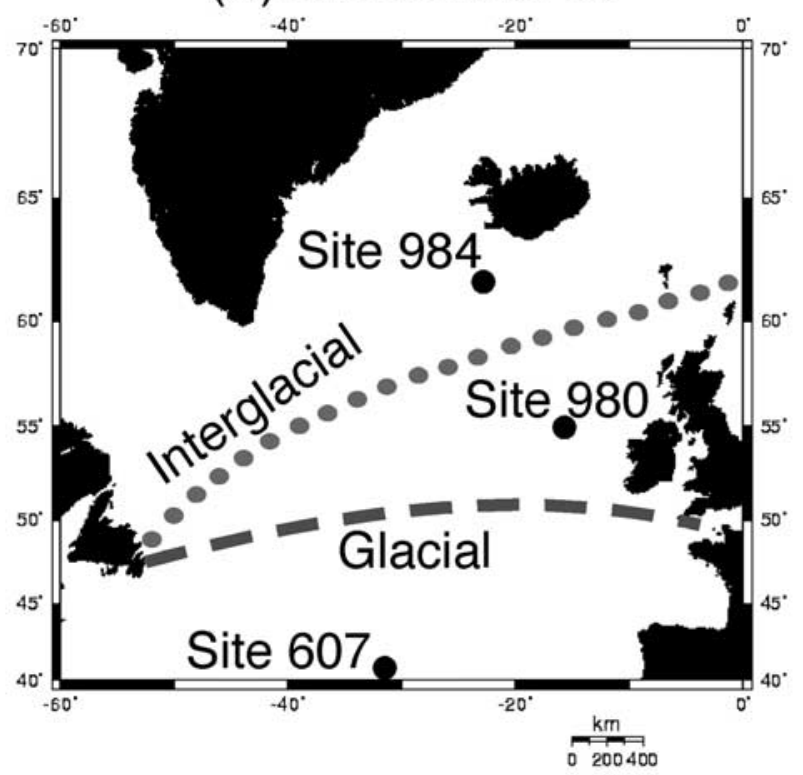

(B) After MIS 16

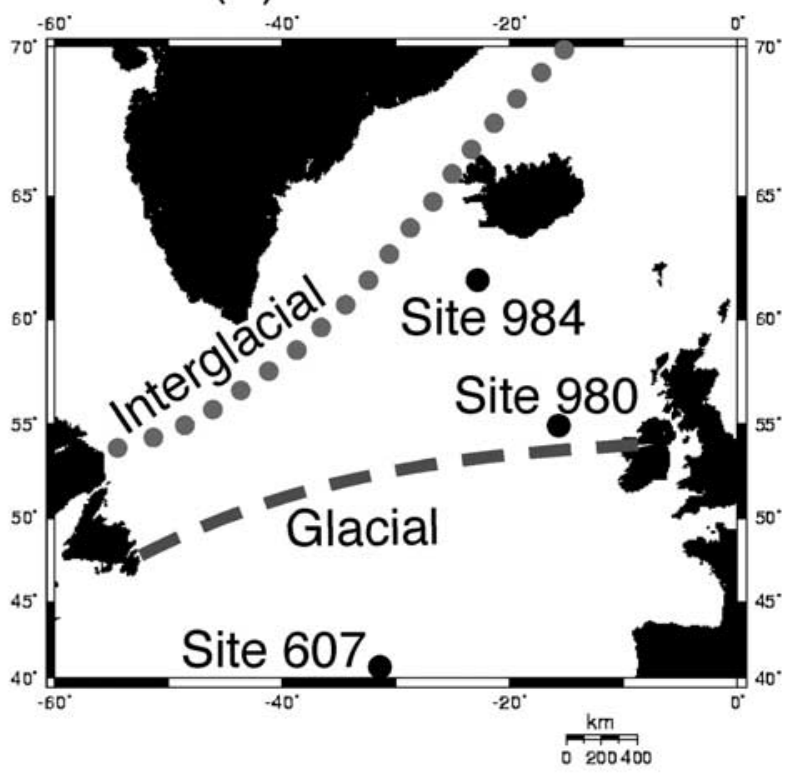

Figure 8. The subpolar North Atlantic showing the average glacial (dashed line) and interglacial (dotted line) Arctic front positions (a) before MIS 16 and (b) after MIS 16. After MIS 16, the interglacial Arctic front moved to more northerly positions similar to the modern Arctic front positions. This may have allowed for greater moisture transport to the subpolar North Atlantic.

long been investigated in the North Atlantic during both glacial terminations and inceptions. Several studies have found that the percentage of the polar foraminifer $N$. pachyderma (s), a common proxy for SST, remained high throughout the deglaciation, defined by the benthic oxygen isotope data [e.g., Oppo et al., 1997, 2001]. This may indicate that surface water warming did not lead global ice-volume decrease. This lag has been difficult to reconcile with a Northern Hemisphere control of global ice-volume changes [e.g., Imbrie et al., 1992, 1993]. However, because the percentage of IRD record indicates that the entire $\delta^{18} \mathrm{O}$ decrease is deglacial in age, a significant part of this decrease may be due to low-salinity subducted meltwater. Accordingly, the interglacial began as the percentage of IRD record approached zero [following Lehman et al., 1993; Raymo et al., 1998; Oppo et al., 2001], followed closely by an increase in SST.

[42] The most well-defined terminations within our record at site 980 were investigated to see how SST and other regional surface water indicators (based on percentage of $N$. pachyderma (s), percentage of IRD, and summer SST) compared to global ice-volume variations $\left(\delta^{18} \mathrm{O}\right)$ and deep circulation $\left(\delta^{13} \mathrm{C}\right)$. Figure 10 shows a typical example of a glacial termination, MIS 20/19, at site 980. The deglacial interval of the termination is denoted by shading and begins with the first decrease in $\delta^{18} \mathrm{O}$, which is close to the age for glacial termination given by Bassinot et al. [1994]. Shading ends with the final return to warm conditions of the surface water indicators. Benthic oxygen isotope values started to decrease at about $795 \mathrm{ka}$. At about $788 \mathrm{ka}$, percentage of $N$. pachyderma (s) and percentage of IRD values decreased, indicating the start of warming in the surface water records.
Full-interglacial conditions were reached within $\sim 1$ kyr. There was a $\delta^{13} \mathrm{C}$ minimum that accompanied the peak in percentage of IRD, suggesting that there may have been a reduction in the relative strength of NADW compared to SOW at this time.

[43] In five of six of the terminations in the $1000-500 \mathrm{ka}$ interval at site 980 , benthic $\delta^{18} \mathrm{O}$ values appear to decrease about 3-10 kyr before SST warming. Associated decreases in benthic $\delta^{13} \mathrm{C}$ and IRD pulses indicate some combination of NADW decrease and SOW increase, as previously shown for the past 1 Myr [Venz et al., 1999; Flower et al., 2000]. Ice-rafting processes may have delayed surface water warming. The $\delta^{13} \mathrm{C}$ values continued to increase well into the interglacial. These findings appear to confirm previous work indicating that the North Atlantic surface waters did not lead ice volume and that NADW recovery continued into the succeeding interglaciation [Imbrie et al., 1992; Oppo et al., 1997; Venz et al., 1999].

[44] After initial warming at about $627 \mathrm{ka}$, there was a return to cool conditions from 624 to $623 \mathrm{ka}$ during the 16/15 termination seen in SST, percentage of IRD, and percentage of $N$. pachyderma (s) records (Figure 9). This abrupt cooling event resembles the Younger Dryas event of the last deglaciation at about $10-11^{14} \mathrm{C}$ years, an event which was characterized by a brief, short-lived return to glacial conditions [e.g., Broecker et al., 1988]. After the cold reversal, SST warmed gradually into the interglacial. Previous work by Sarnthein and Tiedemann [1990] used oxygen isotope data from MIS 2/1 to MIS 18/17 and found Younger Dryasstyle cooling events at all six deglaciations. We found distinct Younger Dryas-type events only at the MIS 16/15 transition and the MIS 22/21 transition (Figures 4 and 9), 


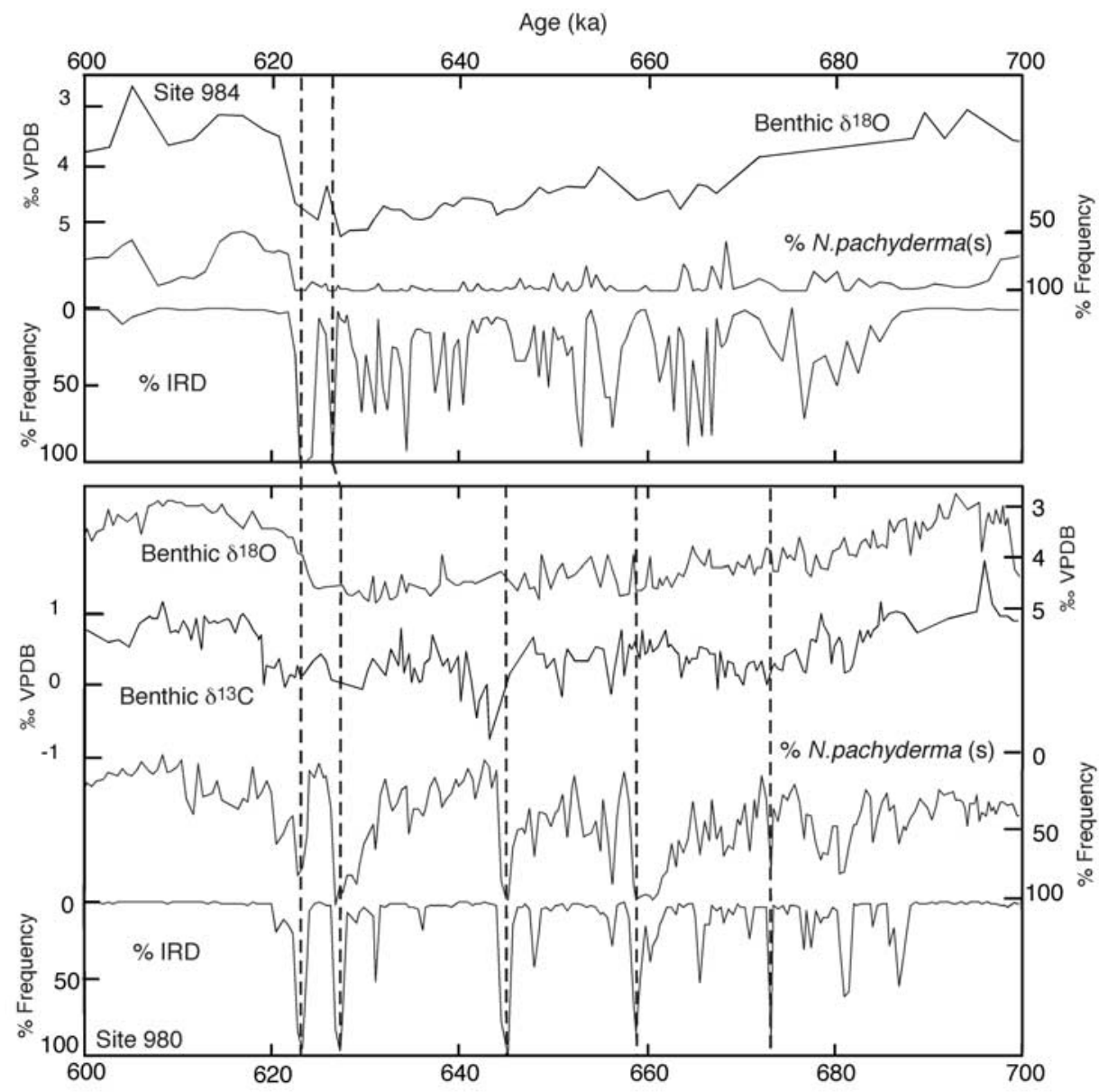

Figure 9. Heinrich-like events during MIS 16, seen as rapid events with very high percentage of IRD and percentage of $N$. pachyderma (s). Dashed lines indicate five Heinrich-like events at Feni drift site 980, some of which do not appear to have counterparts at Bjorn drift site 984.

centered on the termination as during the classic Younger Dryas event of the last deglaciation.

[45] These Younger Dryas-like events cannot be discerned at site 984 , even though our sampling interval is comparable to that at site 980 . These climatic reversals may not have occurred in the site 984 Bjorn drift region because it remained cold throughout the deglaciation. A similar pattern occurs in piston core records of Termination 2 at this location [Oppo et al., 1997, 2001]. Feni drift site 980 may be located in a position that is far more sensitive to millennial-scale climate oscillations such as Younger Dryastype events than the more northwestern Bjorn drift site 984 .

\subsection{Glacial Initiations}

[46] During glacial inceptions, it has long been noted that there may have been a lag of about 6000 years in the North Atlantic SST relative to the 23-kyr precessional cycle of benthic $\delta^{18} \mathrm{O}$ [e.g., Ruddiman and McIntyre, 1981a, 1984; Ruddiman et al., 1980]. This "lagging warmth" was seen as a persistence of low, interglacial-like percentages of the polar foraminifer $N$. pachyderma (s), and warm SST estimates after the time when the oxygen isotope values indicated initiation of the next glaciation.
[47] Our records are of sufficiently high resolution to discern many short (less than $\sim 1 \mathrm{kyr}$ ) variations in the faunal data and in the SST estimates, which showed that although it stays generally warm during the lagging warmth times, there is still significant variability in the records (Figure 11). This may mean that the steady warmth seen in other records may be in part an artifact of lower sample resolution as proposed by Oppo et al. [1997], who suggested that higher-frequency temperature oscillations may help explain the lagging warmth. For example, high-frequency SST variability occurs during lagging warmth at the MIS 5e/5d transition [McManus et al., 1999]. We follow these authors and define lagging warmth as the interval during which faunal SST indices suggest continued peak interglacial warmth within error, allowing for brief cool events. The lagging warmth period ends before the first significant IRD of the following glacial appears. Agreement between two of the three faunally based SST records (percentage of $N$. pachyderma (s), MAT SST, and TFT SST) lends confidence to our interpretation of lagging warmth at each glacial initiation. However, MAT SST appears to decrease before TFT SST during MIS 17/16, $21.5 / 21.4$, and $25 / 24$. Therefore the evidence for lagging 


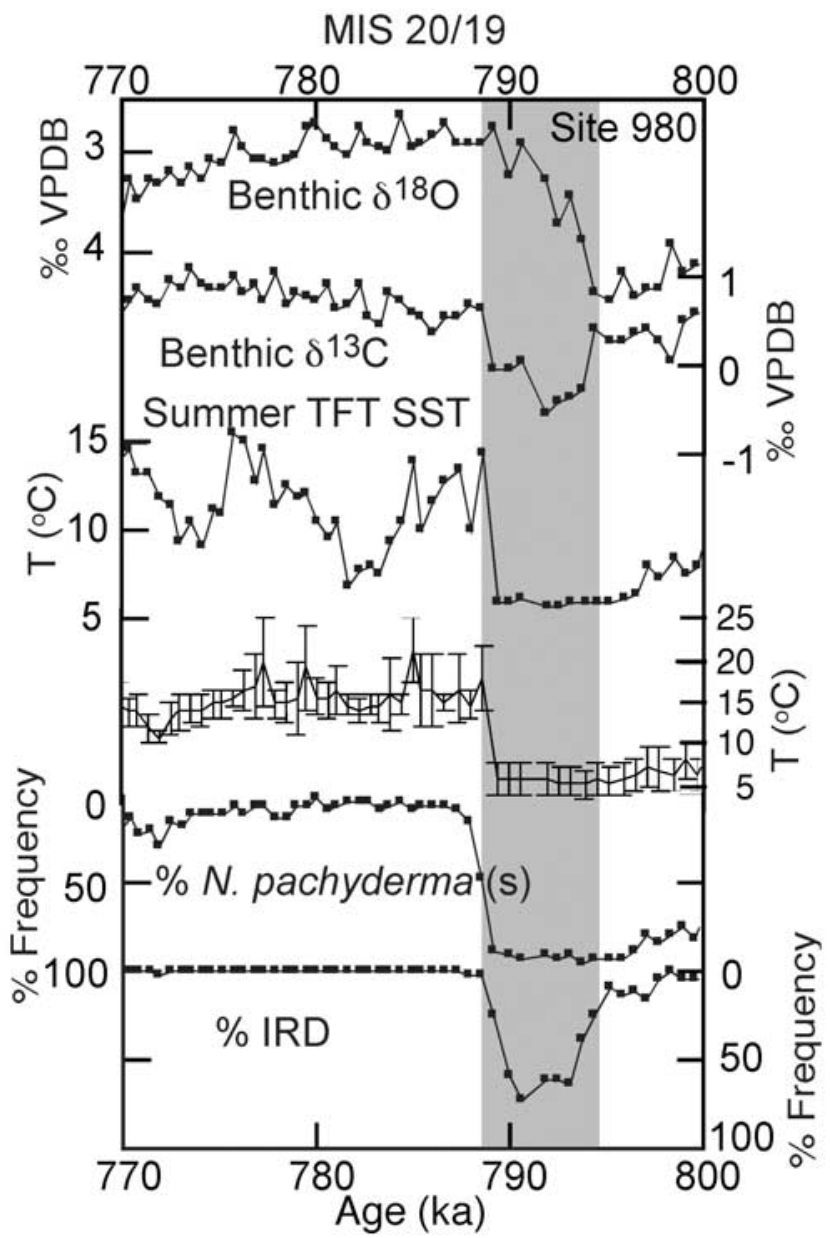

Figure 10. Typical example of a glacial termination, MIS $20 / 19$ at site 980 . The shaded bar highlights the deglacial interval defined as lasting from the first decrease in benthic $\delta^{18} \mathrm{O}$ values to the final disappearance of percentage of IRD [e.g., Lehman et al., 1993; Oppo et al., 2001]. The sequence of events at each termination begins with a benthic $\delta^{18} \mathrm{O}$ decrease, followed by a simultaneous benthic $\delta^{13} \mathrm{C}$ decrease and percentage of IRD increase, accompanied by cool surface waters (TFT SST, MAT SST, and percentage of $N$. pachyderma (s)). Benthic $\delta^{13} \mathrm{C}$ increase (NADW recovery) begins in the middle of the deglacial interval (shaded) followed by rapid decrease in percentage of IRD. As percentage of IRD nears zero, SST increases and percentage of $N$. pachyderma (s) decreases rapidly to full interglacial values, while $\delta^{13} \mathrm{C}$ continues to increase through the interglacial.

warmth at the latter initiations is equivocal. Warm SSTs may have been maintained further south of site 980 such as near site 607 during these intervals (Figure 1).

[48] At the MIS 15/14 glacial initiation, lagging warmth lasting about $14 \mathrm{kyr}$ is seen in the percentage of $N$. pachyderma (s), TFT SST, and MAT SST records. All three records undergo two short intervals of cooling followed by return to warm conditions during this period between the initial $\delta^{18} \mathrm{O}$ increase and the end of the lagging warmth interval. Lagging warmth lasted about $6 \mathrm{kyr}$ at the MIS 17/ 16 initiation, and was seen in the percentage of N. pachyderma (s) and TFT SST records but not in the MAT SST. The percentage of $N$. pachyderma (s) record maintained peak interglacial values for about $3 \mathrm{kyr}$, then began a slow increase for the final $3 \mathrm{kyr}$ of the lagging warmth interval. The TFT SST record showed warming throughout the lagging warmth interval, while the MAT SST began to cool almost immediately after the $\delta^{18} \mathrm{O}$ values began to increase. At the MIS 19/18 glacial initiation the percentage of $N$. pachyderma (s), MAT SST, and TFT SST all showed the lagging warmth interval which lasted almost $10 \mathrm{kyr}$. The percentage of $N$. pachyderma (s) record maintains near-peak interglacial values, gradually increasing throughout the interval. The TFT SST and MAT SST records show some variability while overall maintaining interglacial-like temperatures throughout the interval. The first significant IRD peak occurs at the same time as the abrupt cooling in the three surface records.

[49] The MIS 21.5/21.4 initiation has a lagging warmth interval lasting about $4 \mathrm{kyr}$ in the percentage of N. pachyderma (s) and TFT SST records, but not in the MAT SST record. The percentage of $N$. pachyderma (s) and the TFT SST both maintain peak interglacial values throughout the interval, followed by rapid cooling, while the MAT SST begins to cool at almost the same time as the initial $\delta^{18} \mathrm{O}$ increase.

[50] At the MIS 23/22 glacial initiation (not shown in Figure 11) there is an interval of lagging warmth that lasts about $4 \mathrm{kyr}$ after the benthic $\delta^{18} \mathrm{O}$ began to increase. The cooling is abrupt, and occurs in the TFT SST, MAT SST, and percentage of $N$. pachyderma (s) at the same time.

[51] At the MIS 25/24 initiation, the transition from interglacial to glacial is more gradual. The percentage of $N$. pachyderma (s) and TFT SST records show a lagging wamth of about $8 \mathrm{kyr}$, but the MAT SST record does not. The percentage of $N$. pachyderma (s) maintains interglaciallike values for about $4 \mathrm{kyr}$ and then begins to gradually increase. The TFT warms for about 4 kyr of the lagging warmth interval before it begins to cool gradually. The MAT SST begins to cool almost immediately after the initial $\delta^{18} \mathrm{O}$ increase (Figure 11).

[52] In summary, we found good evidence for lagging warmth lasting $\sim 4-14 \mathrm{kyr}$ at most of our glacial initiations (Figure 11). During each of these intervals, the $\delta^{13} \mathrm{C}$ remained high, indicating that NADW production continued into the glacial initiation as during the late Pleistocene [Oppo et al., 1997]. During the MIS 15/14 and 17/16 initiations, the $\delta^{13} \mathrm{C}$ and the SST began to decrease at approximately the same time. During MIS $21.5 / 21.4, \delta^{13} \mathrm{C}$ continued to rise for about $10 \mathrm{kyr}$ beyond the glacial inception interval. Overall, the ${ }^{13} \mathrm{C}$ evidence indicates continued NADW formation during each glacial initiation, probably derived from areas south of site 980 consistent with a more southerly Arctic front. Because of its association with lagging warmth, we term this phenomenon "lagging NADW production."

[53] At site 984, lagging warmth is not recorded by the percentage of $N$. pachyderma (s) at any of the glacial inceptions. This may indicate that lagging warmth during 

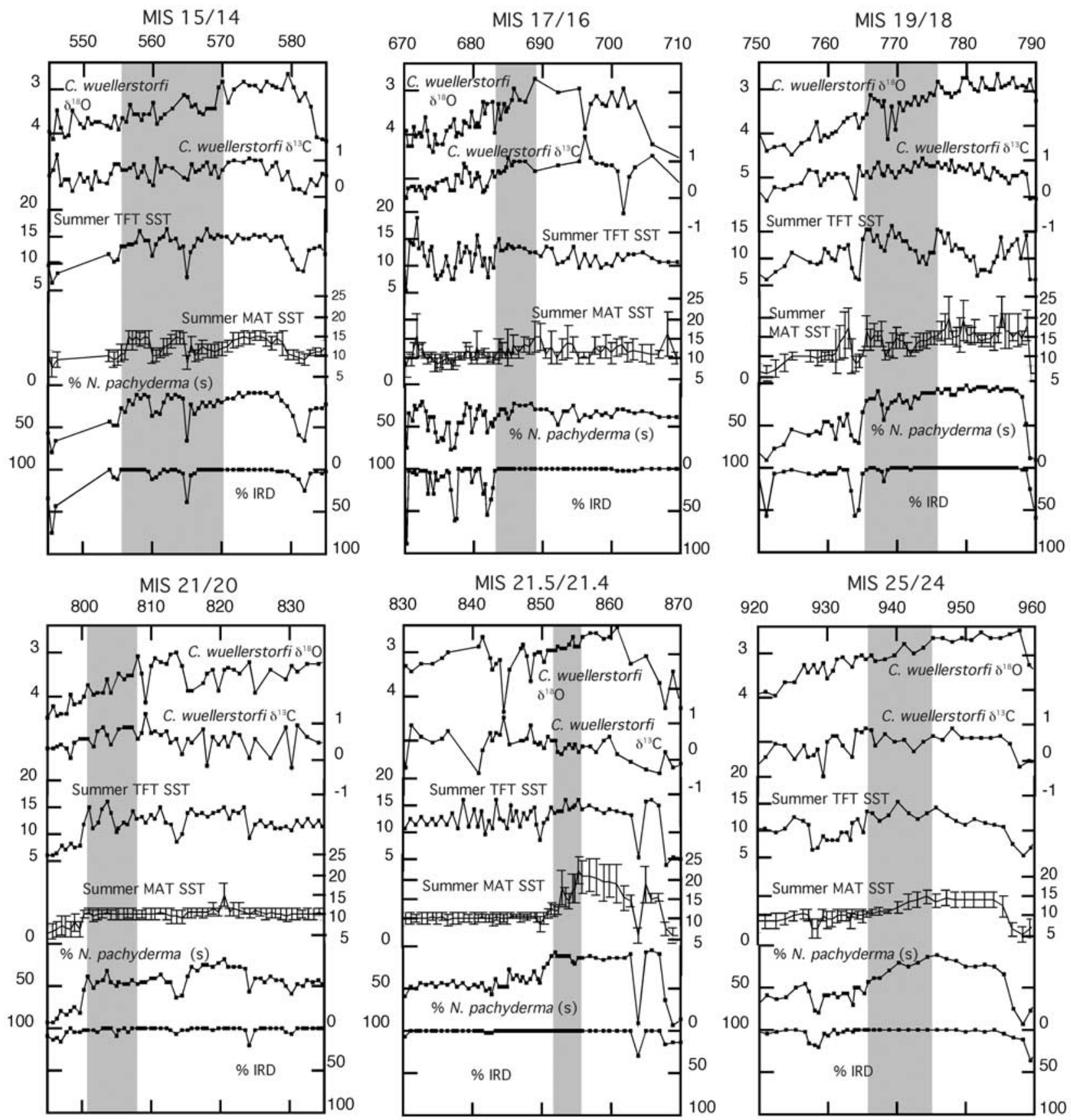

Figure 11. Site 980 glacial initiations. The shaded bars highlight the interval of lagging warmth defined as lasting from the first clear increase of oxygen isotope values until the three SST indicators show cooling (allowing for brief cool events) and before IRD significantly increases.

the mid-Pleistocene was spatially limited and did not affect the more northwestern Bjorn drift area.

[54] Glacial initiations begin with an increase in benthic oxygen isotope records indicating the start of ice sheet growth. As ice growth continued, the salinity of surface waters would increase as fresh water is removed [e.g., Duplessy and Shackleton, 1985]. This would have increased the formation of deep waters in the North Atlantic, recorded as an increase in benthic $\delta^{13} \mathrm{C}$ at North Atlantic sites [e.g.,
Curry et al., 1988; Duplessy et al., 1988; Oppo et al., 1997; McManus et al., 2002]. This would result in an increased northward flow of warm water to replace the subducted waters, increasing heat transport to the region. Warm water may have been a source of moisture to the nearby growing ice sheets through much of the glacial initiation, providing a positive feedback for ice growth [e.g., Ruddiman and McIntyre, 1979, 1981a]. McManus et al. [2002] suggest that this mechanism, including positive feedback between 
surface warmth and continued NADW production, was responsible for lagging warmth in the North Atlantic during the MIS 5e/5d transition.

\section{Conclusions}

[55] The subpolar North Atlantic appears to have had a distinctly different surface oceanography during the midPleistocene than in more recent times. Based on the percentage of N. pachyderma (s) records at two sites, glaciations and interglaciations were slightly cooler during the mid-Pleistocene relative to the late Pleistocene. Significantly, interglacials were distinctly cooler than MIS 5 at Bjorn drift site 984 thoughout the 1000-500 ka interval.

[56] We tracked the approximate position of the North Atlantic Arctic front through comparison of the relative percentages of polar-water indicator N. pachyderma (s) and sea-ice edge indicator T. quinqueloba. At Feni drift, from 700 to $1000 \mathrm{ka}$, there were brief increases in percentage of $T$. quinqueloba following percentage of $N$. pachyderma (s) increases at glacial initiations, which may indicate that at these times the Arctic front was in the Feni drift area, and then moved south during glaciations. Starting at about 660 $\mathrm{ka}$, percentage of $T$. quinqueloba generally increased, indicating that at this time the Arctic front may have shifted to a position closer to Feni drift. Similar shifts occurred at Bjorn drift between 610 and $660 \mathrm{ka}$, indicating that the Arctic front may have continued to migrate north to more strongly influence the Bjorn drift area. Faunal data from sites 980 and 984 therefore indicate that there may have been a change in surface water conditions in the subpolar North Atlantic from about 660 to $610 \mathrm{ka}$, coinciding with the establishment of the 100-kyr world during the MPR.

[57] At all six glacial terminations the sequence of events began with a benthic $\delta^{18} \mathrm{O}$ and $\delta^{13} \mathrm{C}$ decrease, and percentage of IRD increase, which are indicative of deglacial meltwater/IRD pulses and associated NADW decrease. This was followed by an increase in benthic ${ }^{13} \mathrm{C}$ values along with an IRD decrease interpreted as the start of NADW recovery. Rapid $\delta^{13} \mathrm{C}$ increases appear to coincide with SST increases based on the percentage of N. pachyderma (s) and
TFT SST records. Benthic $\delta^{13} \mathrm{C}$ values indicate NADW recovery continued into the interglaciation. This pattern is similar to that found for several late Pleistocene terminations [e.g., Oppo et al., 1997, 2001; Venz et al., 1999] and does not appear to be consistent with North Atlantic circulation as a driver of glacial terminations. However, we note that lead/lag relations at terminations must be interpreted with caution because of low-salinity effects on benthic $\delta^{18} \mathrm{O}$, at least in the mid-depth North Atlantic. The use of full faunal and IRD counts assists in establishing the timing of the glacial to interglacial transition.

[58] When we investigated glacial terminations between 1000 and $500 \mathrm{ka}$, we found evidence for Younger Dryas-like events at MIS 16/15 and 22/21 at site 980 only. This indicates that such events occurred back into the 41-kyr world, but not at every termination, and that these events may have been restricted to the southeastern subpolar North Atlantic.

[59] We find good evidence for lagging warmth (defined as the interval during which faunal SST indices suggest continued peak interglacial warmth within error, allowing for brief cool events) at most of the glacial initiations during the mid-Pleistocene. Each initiation is also associated with "lagging NADW production," based on the observation that high $\delta^{13} \mathrm{C}$ values are maintained into the succeeding glacial initiation. Lagging NADW production occurred even when the Arctic front was located further south than during the late Pleistocene. Together with similar evidence from the Late Pleistocene, these findings indicate that lagging warmth and lagging NADW production are robust features of the North Atlantic climate system that persist in the midto late Pleistocene.

[60] Acknowledgments. We would like to thank Delia Oppo and an anonymous reviewer for detailed comments that greatly improved the manuscript; Jerry McManus, Maureen Rayma, Christina Ravelo, Terry Quinn, and Al Hine for helpful discussion; Phil Howell and David Anderson for MAT and TFT assistance, and Mailee Flower for assistance in generating the stable isotope data. This research used samples provided by the Ocean Drilling Program (ODP). The ODP is sponsored by the U.S National Science Foundation (NSF) and participating countries under the management of Joint Oceanographic Institutions (JOI), Inc. Partial funding for this research was provided by the U.S. Science Support Program (USSSP).

\section{References}

Andersson, C., Transfer function vs. modern analog technique for estimating Pliocene sea-surface temperatures based on planktic foraminiferal data, Western Equatorial Pacific Ocean, J. Foraminiferal Res., 27, 123-132, 1997.

Anderson, D. M., W. L. Prell, and N. J. Barratt, Estimates of sea surface temperature in the Coral Sea at the last glacial maximum, Paleoceanography, 4, 615-627, 1989.

Bassinot, F. C., L. D. Labeyrie, E. Vincent, X. Quidelleur, N. J. Shackleton, and Y. Lancelot, The astronomical theory of climate and the age of the Brunhes-Matuyama magnetic reversal, Earth Planet. Sci. Lett., 126, 91-108, 1994.

Berger, W. H., and E. Jansen, Mid-Pleistocene climate shift: The Nansen connection, in The Polar Oceans and Their Role in Shaping the Global Environment: The Nansen Centennial Volume, AGU, Geophys. Monog., vol. 85, edited by O. M. Johannessen, R. D. Muench, and
J. E. Overland, pp. 295-312, AGU, Washington, D.C., 1994

Berger, W. H., T. Bickert, H. Schmidt, and G. Wefer, Quaternary oxygen isotope record of pelagic foraminifers: Site 806 Ontong Java Plateau, Sci. Results ODP, 130, 381-393, 1993.

Bond, G., et al., Evidence for massive discharges of icebergs into the North Atlantic during the last glacial period, Nature, 360, 245-249, 1992.

Broecker, W. S., The Great Ocean Conveyor, Oceanography, 4, 79-89, 1991.

Broecker, W. S., M. Andree, W. Wolfli, H. Oeschger, G. Bonani, J. P. Kennett, and D. Peteet, The chronology of the last deglaciation: Implications to the cause of the Younger Dryas event, Paleoceanography, 3, 1-19, 1988.

Broecker, W. S., G. Bond, K. Millie, B. Geotges, and W. Willy, A salt oscillator in the glacial Atlantic?, 1, The concept, Paleoceanography, $5,469-477,1990$
CLIMAP, The surface of the ice age earth, Science, 191, 1131-1137, 1976.

CLIMAP, Seasonal reconstruction of the Earth's surface at the last glacial maximum, Geol. Soc. Am. Map Chart Ser MC-36, 1-18, 1981.

Cline, R. M., and J. D. Hays, Investigation of Southern Ocean Paleoceanography and Paleoclimatology, Mem. Geol. Soc., 147, 1976.

Curry, W. B., J.-C. Duplessy, L. D. Labeyrie, and N. J. Shackleton, Changes in the distribution of $\delta^{13} \mathrm{C}$ of deep water $\mathrm{CO}_{2}$ between the last glaciation and the Holocene, Paleoceanography, 3, 317-341, 1988.

Duplessy, J.-C., and N. J. Shackleton, Response of global deep-water circulation to Earth's climatic change 135,000-107,000 years ago, Nature, 316, 500-507, 1985.

Duplessy, J.-C., N. J. Shackleton, R. G. Fairbanks, L. D. Labeyrie, D. Oppo, and N. Kallel, Deepwater source variations during the last climatic cycle and their impact on the global 
deepwater circulation, Paleoceanography, 3, $343-360,1988$

Flower, B. P., Data Report: Planktonic foraminifers from the subpolar North Atlantic and Nordic Seas: Sites 980-987, 907, in Proceedings of the Ocean Drilling Program, Scientific Results, 162, edited by E. Jansen et al., pp. 19-34, Ocean Drill. Prog., College Station, Texas, 1999.

Flower, B. P., D. W. Oppo, J. F. McManus, K. A. Venz, D. A. Hodell, and J. L. Cullen, North Atlantic intermediate to deep water circulation and chemical stratification during the past 1 Myr, Paleoceanography, 15, 388-403, 2000.

Guiot, J., Methods and programs of statistics for paleoclimatology and paleoecology, in Quantification des Changements Climatiques: Methodes et Programmes: Monographie I, edited by J. Guiot and L. Labeyrie, pp. 1-258, Cent. Univ. of Arles, Arles, France, 1991.

Heinrich, H., Origin and consequences of cyclic ice-rafting in the northeast Atlantic Ocean during the past 130,000 years, Quat. Res., 29, $142-152,1988$

Helland-Hansen, B., and F. Nansen, The Norwegian Sea. Its physical oceanography based upon the Norwegian researches 1900-1904, Reports on Norwegian Fishery and Marine Investigations, 2, 1-359, 1909.

Hewitt, C. D., A. J. Broccoli, J. F. B. Mitchell, and R. J. Stouffer, A coupled model study of the last glacial maximum: Was part of the North Atlantic relatively warm?, Geophys. Res. Lett., 28, 1571-1574, 2001

Hutson, W. H., The Agulhas current during the late Pleistocene: Analysis of modern faunal analogs, Science, 207, 64-66, 1979.

Hutson, W. H., and W. L. Prell, A paleoecological transfer function, FI 2, for Indian Ocean planktonic foraminifera, J. Paleontol., 54, $381-399,1980$.

Imbrie, J., and J. Z. Imbrie, Modeling the climatic response to orbital variations, Science, 207, 943-953, 1980

Imbrie, J., and N. G. Kipp, A new micropaleontological method for quantitative paleoclimatology: Application to a late Pleistocene Caribbean core, The Late Cenozoic Glacial Ages, Yale Univ. Press, New Haven-Lodon, $71-147,1971$.

Imbrie, J., et al., On the structure and origin of major glaciation cycles 1 . Linear responses to Milankovitch forcing, Paleoceanography, 7, $701-738,1992$

Imbrie, J., et al., On the structure and origin of major glaciation cycles 2 . The 100,000 year cycle, Paleoceanography, 8, 699-735, 1993.

Jansen, E., et al., Proceedings of Ocean Drilling Program, Initial Reports, 162, pp. 5-20, College Station, Texas (Ocean Drilling Program), 1996.

Johannessen, T., E. Jansen, A. Flatoy, A. C. Ravelo. The relationship between surface water masses, oceanographic fronts and paleoclimatic proxies in surface sediments of the Greenland, Iceland, Norwegian seas, NATO ASI Series, vol. 117, edited by R. Zahn et al., Springer-Verlag, New York, 61-85, 1994.

Lehman, S. J., and L. D. Keigwin, Sudden changes in North Atlantic circulation during the last deglaciation, Nature, 356, 757-762, 1992.

Lehman, S. J., D. G. Wright, and T. Stocker, Transport of freshwater into the deep ocean by the Conveyor, in Ice in the Climate System, NATO ASI Ser., vol. 12(1), edited by W. R. Peltier, pp. 187-209, Springer-Verlag, New York, 1993.
Maasch, K. A., Statistical detection of the midPleistocene transition, Climate Dyn., 2, 133143, 1988.

McCartney, M. S., and L. D. Talley, Warm-to-cold conversion in the northern North Atlantic Ocean, J. Phys. Oceanogr., 14, 922-935, 1984.

McCave, I. N., B. Manighetti, and N. A. S. Beveridge, Circulation in the glacial North Atlantic inferred from grain-size measurements, Nature, 374, 149-152, 1995.

McManus, J. F., D. W. Oppo, and J. L. Cullen, A 0.5 -million-year record of millennial-scale climate variability in the North Atlantic, Science, 238, 971-975, 1999.

McManus, J. F., D. W. Oppo, L. D. Keigwin, J. L. Cullen, and G. C. Bond, Thermohaline circulation and prolonged interglacial warmth in the North Atlantic, Quat. Res., 58(1), 17 21, 2002.

Mix, A. C., N. G. Pisias, R. Zahn, W. Rugh, J. Wilson, A. Morey, and T. K. Hagelberg, Benthic foraminifer stable isotope record from site $849(0-5 \mathrm{Ma})$ : Local and global climate changes, Proc. Ocean Drill. Program Sci. Res., 138, 371-412, 1995.

Mudelsee, M., and M. Schulz, The Mid-Pleistocene climate transition: Onset of $100 \mathrm{ka}$ cycle lags ice volume build-up by $280 \mathrm{ka}$, Earth Planet. Sci. Lett., 151, 117-123, 1997.

Oppo, D. W., M. Horowitz, and S. Lehman, Marine core evidence for reduced deep water production during Termination II followed by a relatively stable substage $5 \mathrm{e}$ (Eemian), Paleoceanography, 12, 51-63, 1997.

Oppo, D. W., L. D. Keigwin, J. F. McManus, and J. L. Cullen, Persistent suborbital climate variability in marine isotope stage 5 and Termination II, Paleoceanography, 16, 280-292, 2001.

Pisias, N. G., and T. C. Moore, The evolution of Pleistocene climate: A time series approach, Earth Planet. Sci. Lett., 52, 450-456, 1981.

Prell, W. L., Oxygen and carbon isotope stratigraphy for the Quaternary of Hole 502B: Evidence for two modes of isotope variability, Deep Sea Drill. Project Initial Rep., 68 , 455-464, 1982

Prell, W. L., The stability of low-latitude sea surface temperatures: An evaluation of the CLIMAP reconstruction with emphasis on the positive SST anomalies, Technical report for the Department of Energy, TRO25, Brown Univ., Providence, RI, 1985.

Prell, W. L., J. Imbrie, D. G. Martinson, J. J. Morley, N. G. Pisias, N. J. Shackleton, and H. F. Streeter, Graphic correlation of oxygen isotope stratigraphy application to the late Quaternary, Paleoceanography, 1, 137-162, 1986.

Prell, W., A. Martin, J. Cullen, and M. Trend, The Brown University Foraminiferal Data Base, IGBP PAGES/World Data Center-A for Paleoclimatology Data Contribution Series \# 1999-027, NOAA/NGDC Paleoclimatology Program, Boulder CO, USA, 1999.

Rahmstorf, S., Rapid climate transitions in a coupled ocean-atmosphere model, Nature, 372, 82-85, 1994

Raymo, M. E., The timing of major climate terminations, Paleoceanography, 12, 577-585, 1997.

Raymo, M. E., W. F. Ruddiman, J. Backman, B. M. Clement, and D. G. Martinson, Late Pliocene variation in northern hemisphere ice sheets and North Atlantic deep water circulation, Paleoceanography, 4, 413-446, 1989.

Raymo, M. E., D. W. Oppo, and W. Curry, The mid-Pleistocene climate transition: A deep sea carbon isotope perspective, Paleoceanography, 112, 546-559, 1997.
Raymo, M. E., K. Ganley, S. Carter, and D. W. Oppo, Millennial-scale climate instability during the early Pleistocene epoch, Nature, 392 699-702, 1998

Ruddiman, W. F., Late Quaternary deposition of ice-rafted sand in the sub-polar North Atlantic (lat. 40-65N), Geol. Soc. Am. Bull., 88, $1813-$ $1827,1977$.

Ruddiman, W. F., and A. Esmay, A streamlined foraminiferal transfer function for the subpola North Atlantic, Initial Rep. Deep Sea Drill. Project, 94, 1045-1057, 1987.

Ruddiman, W. F., and A. McIntyre, Warmth of the subpolar North Atlantic Ocean during Northern Hemisphere ice-sheet growth, Science, 204. $173-175,1979$.

Ruddiman, W. F., and A. McIntyre, The mode and mechanism of the last deglaciation: Oceanic evidence, Ouat. Res., 16, 125-134, 1981a.

Ruddiman, W. F., and A. McIntyre, Oceanic mechanisms for amplification of the 23,000-year ice volume cycle, Science, 212, 617-627, $1981 b$

Ruddiman, W. F., and A. McIntyre, Ice-age thermal response and climatic role of the surface Atlantic Ocean, $40^{\circ} \mathrm{N}$ to $63^{\circ} \mathrm{N}$, Geol. Soc. Am. Bull., 95, 381-396, 1984.

Ruddiman, W. F., B. Molfino, A. Esmay, and E. Pokras, Evidence bearing on the mechanism of rapid deglaciation, Clim. Change, 3, 65-87, 1980.

Ruddiman, W. F., A. McIntyre, and M. Raymo, Paleoenvironmental results from North Atlantic sites 607 and 609, Initial Rep. Deep Sea Drill. Project, 94, 855-878, 1987.

Ruddiman, W. F., M. E. Raymo, D. G. Martinson, B. M. Clement, and J. Backman, Pleistocene evolution of Northern Hemisphere climate, $\mathrm{Pa}$ leoceanography, 4, 353-412, 1989.

Sarnthein, M., and R. Tiedemann, Younger Dryas-style cooling events at glacial terminations I-VI at ODP site 658: Associated benthic $\delta^{13} \mathrm{C}$ anomalies constrain meltwater hypothesis, Paleoceanography, 5, 1041-1055, 1990.

Schmitz, W. J., and M. S. McCartney, On the North Atlantic circulation, Rev. Geophys., 31 , 29-49, 1993.

Schmieder, F., T. von Dobeneck, and U. Bleil, The mid-Pleistocene climate transition as documented in the deep South Atlantic Ocean: Initiation, interim state and terminal event Earth Planet. Sci. Lett., 179, 539-549, 2000.

Shackleton, N. J., A. Berger, and W. R. Peltier, An alternative astronomical calibration of the lower Pleistocene timescale based on ODP site 677, Trans.R. Soc. Edinburgh Earth Sci., 81, 251-261, 1990.

Shipboard Scientific Party, Sites 980/981, in Proceedings of Ocean Drilling Program Initial Reports, 162, edited by E. Jansen et al., pp. 49-90, Ocean Drill. Prog., College Station, Tex., 1996.

Van Weering, T. C. E., and S. de Rijk, Sedimentation and climate-induced sediments on Fen Ridge, Northeast Atlantic Ocean, Mar. Geol., 101, 49-69, 1991

Venz, K. A., D. A. Hodell, C. Stanton, and D. A Warnke, A 1.0 Myr record of Glacial North Atlantic Intermediate Water variability from ODP site 982 in the northeast Atlantic, Paleoceanography, 14, 42-52, 1999.

B. P. Flower and A. K. Wright, College of Marine Science, University of South Florida, 140 7th Ave. South, St. Petersburg, FL 33701, USA. (bflower@marine.usf.edu; awright@marine.usf. edu) 